\title{
Current Insights and Latest Updates in Sperm Motility and Associated Applications in Assisted Reproduction
}

\author{
Reyon Dcunha ${ }^{1}$ - Reda S. Hussein ${ }^{2,3}$ - Hanumappa Ananda ${ }^{1}$ Sandhya Kumari ${ }^{1}$. Satish Kumar Adiga ${ }^{1}$. \\ Nagarajan Kannan ${ }^{4,5,6}$. Yulian Zhao ${ }^{2,7}$ (1) Guruprasad Kalthur ${ }^{1,4}$
}

Received: 22 July 2020 / Revised: 08 October 2020 / Accepted: 01 November 2020 / Published online: 7 December 2020

(C) The Author(s) 2020

\begin{abstract}
Spermatozoon is a motile cell with a special ability to travel through the woman's reproductive tract and fertilize an oocyte. To reach and penetrate the oocyte, spermatozoa should possess progressive motility. Therefore, motility is an important parameter during both natural and assisted conception. The global trend of progressive reduction in the number and motility of healthy spermatozoa in the ejaculate is associated with increased risk of infertility. Therefore, developing approaches for maintaining or enhancing human sperm motility has been an important area of investigation. In this review we discuss the physiology of sperm, molecular pathways regulating sperm motility, risk factors affecting sperm motility, and the role of sperm motility in fertility outcomes. In addition, we discuss various pharmacological agents and biomolecules that can enhance sperm motility in vitro and in vivo conditions to improve assisted reproductive technology (ART) outcomes. This article opens dialogs to help toxicologists, clinicians, andrologists, and embryologists in understanding the mechanism of factors influencing sperm motility and various management strategies to improve treatment outcomes.
\end{abstract}

Keywords Assisted reproductive technology $\cdot$ Male infertility $\cdot$ Sperm motility $\cdot$ Sperm motility enhancers

\section{Introduction}

The human spermatozoon is an extremely specialized motile cell with a highly condensed nucleus and scanty cytoplasm. Even though transcriptionally and translationally inactive, it has precise metabolic pathways which are fundamental for fertilization to take place. After its production in the seminiferous tubules, the sperm undergoes maturation in the epididymis and then travels through the female reproductive tract to facilitate the transfer of paternal genome into the oocyte. Spermatozoa, which are deposited in the vagina during coitus, must reach the site of

Guruprasad Kalthur

guru.kalthur@manipal.edu

Yulian Zhao

Zhao.Yulian@mayo.edu

1 Department of Clinical Embryology, Kasturba Medical College, Manipal, Manipal Academy of Higher Education, Manipal 576104, India

2 Division of Reproductive Endocrinology and Infertility, Department of Obstetrics and Gynecology, Mayo Clinic, 200 1st St SW,

Rochester, MN 55905, USA fertilization - namely ampullary site of the uterine tube (also known as fallopian tube). To reach the ampulla, in addition to the self-propelling properties of spermatozoa (forward progressive motility), the female reproductive tract assists in this process, which is regulated by the female reproductive hormones. Therefore, among all the semen parameters, sperm motility is considered to be a strong predictive marker of male fertility potential [1]. Based on studies with excised human uterus and tubes, it is estimated that human spermatozoa travel an average distance of approximately $19 \mathrm{~cm}$ and undergoes several physiological and biochemical changes before meeting an oocyte [2].

3 Department of Obstetrics and Gynecology, Assiut University, Assiut City, Egypt

4 Division of Experimental Pathology and Laboratory Medicine, Department of Laboratory Medicine and Pathology, Mayo Clinic, Rochester, MN 55905, USA

5 Center for Regenerative Medicine, Mayo Clinic, Rochester, MN 55905, USA

6 Mayo Clinic Cancer Center, Mayo Clinic, Rochester, MN 55905, USA

7 Department of Laboratory Medicine and Pathology, Mayo Clinic, Rochester, MN 55905, USA 
Based on the pattern of movement and velocity, spermatozoa can be graded as progressively motile, non-progressive (exhibiting only lateral head displacement), and immotile. As per the recent guidelines of the World Health Organization [3], the reference values for human semen characteristics are specified in Table 1. Men with ejaculates showing less than $40 \%$ total motile or $32 \%$ progressively motile spermatozoa are considered to be asthenozoospermic, a condition characterized by disorders in sperm motility [4]. Asthenozoospermia is considered as one of the predominant contributing factors for male infertility [5]. The purpose of this review is to recapitulate the physiology and signaling cascade of sperm motility, common disorders and factors which affect motility, importance of motility in assisted reproductive technology (ART), and possible approaches to improve motility in spermatozoa.

\section{Structure of Human Spermatozoa}

Sperm motility is controlled by its complex, structural and molecular signaling mechanisms. Broadly, spermatozoa are divided into three main parts - the head, which contains nuclear material; the tail or flagellum, which contains the machinery needed to propel the spermatozoa forward; and neck or connecting piece, which connects the head to flagellum (Fig. 1). The flagellum can be further segregated into the midpiece (containing cellular organelles like mitochondria), principal piece, and end piece [6].

The pivotal part of the sperm flagellum is the axoneme, which originates at the connecting piece and terminates at the end piece. It is composed of 9 microtubule doublets and a central pair, commonly termed the $9+2$ arrangement (Fig. 1). These 9 microtubules are controlled by nexin links that connect to the central pair by radial spokes. Inner and outer axonemal dynein arms, which are key to acquiring motility in sperm, project from the microtubule doublets. The dynein arms help in sliding the microtubule doublets by consuming adenosine triphosphate (ATP) [7].

Table 1 Lower reference limits for semen characteristics [3]

\begin{tabular}{ll}
\hline Parameters & Lower reference limit \\
\hline Volume (mL) & 1.5 \\
Total sperm number $\left(10^{6}\right.$ per ejaculate) & 39 \\
Sperm concentration $\left(10^{6}\right.$ per $\left.\mathrm{mL}\right)$ & 15 \\
Total motility (Progressive + Non progressive, \%) & 40 \\
Progressive motility (\%) & 32 \\
Vitality (live spermatozoa, \%) & 58 \\
Sperm morphology (normal forms, \%) & 4 \\
pH & $\geq 7.2$ \\
\hline
\end{tabular}

In mammalian sperm, the axoneme is covered by accessory structures, such as the outer dense fibers (ODFs), fibrous sheath (FS), and mitochondrial sheath (MS). In the midpiece, the axoneme is surrounded by ODFs and MS. In humans, the MS is spirally wound around the axoneme, which provides energy in the form of ATP required for sperm motility. In the principal piece, the axoneme is surrounded by ODFs and FS. The ODFs are petal-shaped structures that lie directly above the axoneme microtubule doublets which progressively decrease in diameter from base to tip of the principal piece. It is the principal piece that renders shape and flexibility to the tail. In addition to this, the principal piece provides room for signaling proteins that regulate motility and those involved in capacitation and hyperactivation. No accessory structures between the axoneme and plasma membrane are present in the end piece [8].

\section{Risk Factors Affecting Sperm Motility}

Human ejaculate is highly heterogenous with respect to motility, morphology, and other functional characteristics of spermatozoa. Globally, about 20 to $30 \%$ of infertility cases are due to sperm-related problems in men of reproductive age [9]. There is strong evidence to suggest that lifestyle and other environmental factors contribute considerably to semen disorders leading to male infertility (Fig. 2). Even though these factors affect different semen parameters, in the context of this article, we focus mainly on the important factors that are known to affect sperm motility.

\section{Varicocele}

Varicocele is a common chronic pathology in men, caused by abnormal dilatation of veins in the scrotum that leads to impairment of regular semen parameters. A systematic review and meta-analysis revealed that varicocele is strongly correlated with poor semen profile [10]. A compromised testicular microenvironment due to elevated levels of highly reactive oxidants and reduced levels of antioxidant is commonly observed in this condition [11]. Plenty of evidence in the literature suggests that varicocele is associated with poor sperm motility [10-12]. A high percentage of inactive mitochondria [13], abnormal expression of mitochondrial proteins [14], decrease in ATP levels [13], and altered calcium signaling cascade [15] in spermatozoa of men with varicocele has been reported in the literature. Significant decrease in kinematic parameters, such as curvilinear velocity (VCL), straight line velocity (STR), and amplitude of lateral head displacement $(\mathrm{ALH})$, was observed in men with varicocele [16]. However, it remains inconclusive whether the surgical procedures like varicocelectomy improves the sperm motility [17-19]. Further, efforts to improve the semen characteristics using 


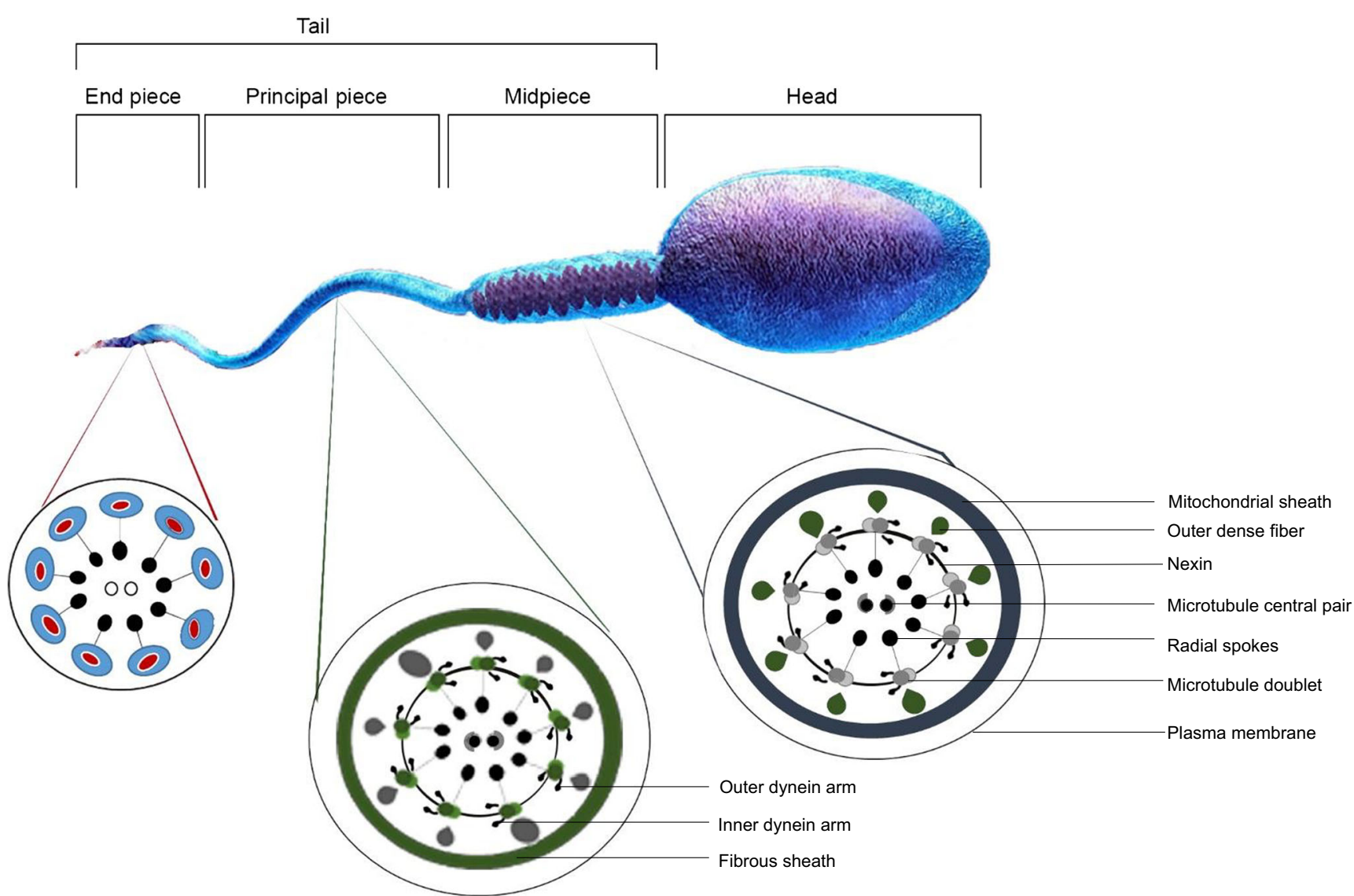

Fig. 1 Structure of mature human spermatozoon and cross section of flagella at various segments of the tail

micronutrient and antioxidant supplements have shown some promising results $[20,21]$.

\section{Genetic Abnormalities Associated with Sperm Motility Disorders}

Sperm motility depends upon the flagellar structure and function. Several reports indicate the association of poor motility with genetic defects [22-24]. The most common conditions are primary ciliary dyskinesia (PCD) and Kartagener syndrome. These are autosomal recessive disorders with an incidence of 1 in 20,000 and 1 in 30,000, respectively [24, 25]. In these conditions, spermatozoa lack motility due to defective dynein arms, with half of the cases having defects in the formation of the central pair complex and radial spokes. Lack of sperm motility is observed in $90 \%$ of PCD disease conditions and involves the outer and inner dynein arms or both of the PCD-associated genetic mutations of the dynein genes [23]. Dysplasia of FS is one of the structural flagellar abnormalities observed in spermatozoa, characterized by hyperplasia and hypertrophy of the FS. In this condition, the midpiece is invaded by the hypertrophied FS, and the annulus is predominantly not formed [22]. Dysplasia of FS was shown to have a familial predisposition in $20 \%$ of cases. However, to date, there is no consensus about the genetic background of dysplasia of FS [26].

\section{Mitochondrial DNA Mutations and Sperm Motility}

Mitochondria are an important source of energy required for sperm motility. Usually, abnormalities of the MS or mitochondrial membrane integrity are associated with sperm motility disorders [27]. Deletions or mutations in mitochondrial DNA are correlated with elevated oxidative stress, sperm immotility, and male infertility [28, 29]. In addition, researchers have identified polymorphic mutations in genes encoding the oxidative phosphorylation complexes and transfer RNA of mitochondrial DNA associated with low sperm motility [30]. A missense mutation (C119941) in the mitochondrial ND4 (NADH dehydrogenase 4) gene has also been reported as the reason for low sperm motility [31]. Further studies are necessary to unravel the genetic association between sperm motility using advanced techniques like whole exome sequencing or appropriate animal models.

\section{Antisperm Antibodies}

It has been postulated that antisperm antibodies (ASAs), an autoimmune condition, can significantly affect male fertility 


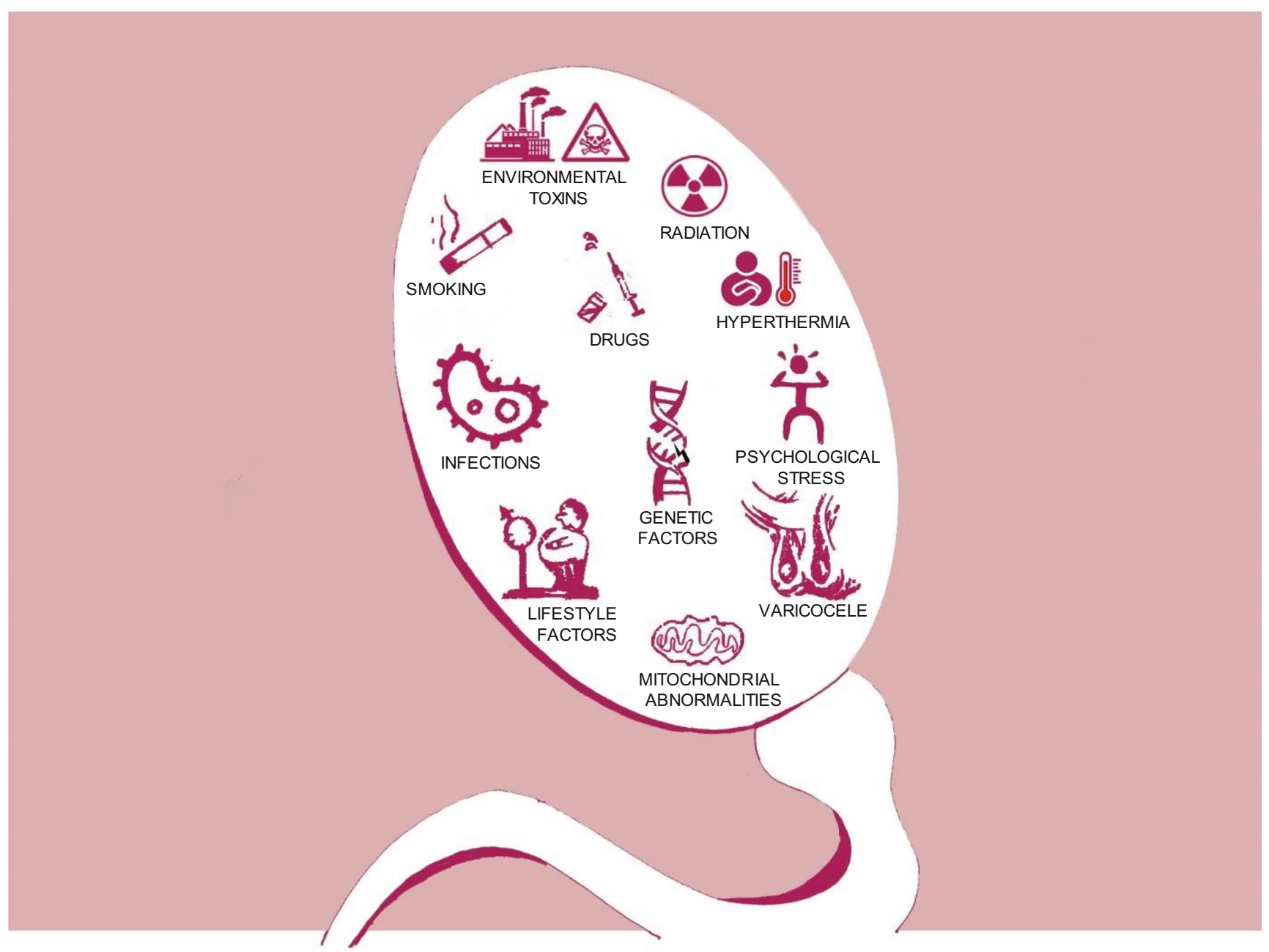

Fig. 2 Factors which affect human sperm motility

due to poor sperm motility [32]. Roughly, 6 to $11 \%$ of male patients with infertility are known to have ASAs in their seminal plasma [33]. ASAs are known to hinder progressive motility and block sperm-egg interaction. This autoimmune condition can either be spontaneous or idiopathic and is mostly found in homosexual men and patients with varicocele, testicular trauma, mumps, orchitis, congenital absence of the vas, and spinal cord injury, as well as in those who have undergone vasectomy [34]. The mechanism by which ASAs cause reduced sperm motility is mainly due to the entangling of the spermatozoa at specific regions (head to head, head to midpiece, head to tail, or non-specific binding), due to the binding of immunoglobulins to sperm surfaces. Several methods to reduce ASA in the semen have been explored. Corticosteroid treatment [35], proteolytic enzyme treatment [36], use of immunobeads [37], and immunomagnetic sperm separation methods [38] have shown significant beneficial role. However, in assisted conception and assisted reproduction, the sperm-washing process may be sufficient to get rid of ASAs [39, 40].

\section{Sexual Abstinence}

Human spermatozoa gain motility potential during their epididymal transit, which is around 2-11 days [41]. During their transport and storage in epididymis, spermatozoa undergo series of physiological and biochemical changes to acquire fertilizing ability. Considering these facts, WHO has recommended 2-7 days as an ideal abstinence time for assessing the semen parameters [3]. However, it is important to note that prolonged sexual abstinence can lead to accumulation of spermatozoa in epididymis, which has limited ability to provide a conducive environment to spermatozoa for long time [42]. Elevated oxidative stress and poor antioxidant defense in the epididymal microenvironment may compromise the sperm parameters under such circumstances. Studies suggest that spermatozoa are highly vulnerable to oxidative stress due to the elevated level of polyunsaturated fatty acids (PUFA) in the spermatozoa membrane [43, 44]. A study undertaken by Comar et al. [42] in 2458 men reported a significant negative effect of abstinence on sperm viability, motility, and mitochondrial membrane potential. Considering the poor sperm 
quality with prolonged abstinence, discrepancies between researchers over the ideal abstinence for therapeutic insemination procedures continue. Shen et al. [45] reported that ejaculates collected from men with short abstinence $(1-3 \mathrm{~h})$ period compared to 3-7 days of abstinence showed increased sperm concentration and higher percentage of motile spermatozoa. Better sperm velocity, progressiveness, and hyperactivation were observed when the abstinence period was $2 \mathrm{~h}$ compared to 4-7 days [46]. This was true for oligozoospermic men as well. Dupesh et al. [47] reported that $<24 \mathrm{~h}$ abstinence in oligozoopermic men had highest percentage of progressively motile sperm and normal morphology. However, these studies reported lower sperm count and volume. Contrary to this, Elzanaty et al. [48] reported higher percentage of motile spermatozoa at 4-5 days as compared to 2-3 and 6-7 days of abstinence.

\section{Lifestyle and Demographic Factors Related to Sperm Motility}

Environmental and lifestyle factors have shown to affect semen quality. Most of the studies have indicated strong correlation between alcohol intake and decreased sperm motility [49-51], whereas few studies have shown no effect $[52,53]$. Studies have shown that abstinence from alcohol consumption can reverse the adverse effect of alcohol on motility [54, 55]. Tobacco inhalation is another common lifestyle factor known to contribute to compromised semen parameters. Inhalation of large number of toxins from tobacco smoking can affect spermatogenesis and semen quality, including motility. Even moderate smoking was shown to have significant adverse effects on progressive motility [56]. Tobacco smoke contains nicotine as the main hazardous chemical along with traces of tar, carbon monoxide, polycyclic aromatic hydrocarbons, and heavy metals [57]. However, an in vitro experiment demonstrated that nicotine and cotinine are not responsible for the decrease in motility. Hence, other components, such as carbon monoxide, hydrogen cyanide, alcohols, ammonia, volatile hydrocarbons, aldehydes, and ketones may result in decreased sperm motility [58]. The decrease in motility could also be due to the epididymal dysfunction in smokers or elevated oxidative stress in the testicular environment [57]. High malondialdehyde (MDA) and protein carbonyl levels and low levels of glutathione S-transferase (GST) and reduced glutathione (GSH) were reported in seminal plasma and spermatozoa of smokers [59]. Other factors such as high body mass index [60], meat intake frequency [61], intense physical activity [62], prolonged cell phone [63] and laptop usage [64], and lack of sleep [65] are considered as potential risk factors for decrease in sperm motility. Therefore, lifestyle modification such as consuming nutritious diet, regular exercise, and withdrawal from substance abuse, smoking, and alcohol consumption can improve semen parameters considerably $[54,66]$.

\section{Drugs Affecting Sperm Motility}

There is sufficient evidence in the literature indicating the deleterious effect of chemotherapeutic drugs on spermatogenesis in cancer patients [67-69]. While the negative effect of chemotherapeutic drugs on sperm production is well documented, their effect on sperm motility remains unclear. Animal studies have demonstrated that anticancer drugs such as vincristine, cisplatin, and cyclophosphamide impair epididymal function, thereby affecting sperm motility [70]. Literature indicates that other commonly used medications have considerable adverse effects on sperm motility. In vitro studies have shown that psychotropic drugs (imipramine hydrochloride, desmethylimipramine, chlorpromazine, trifluoperazine, and nortriptyline hydrochloride) act as potent inhibitors of sperm motility [71]. Antiepileptic drugs (phenytoin, carbamazepine, and valproate) had adverse effects on motility both in vivo and in vitro [72]. Consumption of high amounts of acetaminophen (commonly known as paracetamol), an antipyretic, has also shown to decrease sperm motility [73]. Lansoprazole, a proton pump inhibitor used to treat gastric illness, has shown to reduce the motility due to its calcium quenching effect or decreased $\mathrm{Na}^{+}-\mathrm{K}^{+}$-ATPase activity [74]. Moderate consumption of aspirin, a non-steroidal anti-inflammatory drug (NSAID), is known to demonstrate similar effects in young men [75]. In addition, regular consumption of recreational drugs, such as marijuana, is shown to affect spermatogenesis as well as sperm motility [76]. However, there are no clear reports in the literature to suggest whether the effects of these drugs on motility are reversible or irreversible.

\section{Radiation}

Radioactivity (natural or by human activity) is an inevitable element surrounding humans. Exposure to radioactivity may be primarily due to occupational environments (mine fields, medical setups, flights at altitude of above $10,000 \mathrm{~m}$ ) or patients who receive radiation as a part of diagnostic or therapeutic procedure. Some geographic locations may naturally have high radioactivity in their surroundings in the form of gases, such as radon or radionuclides in rocks [77]. Testes are considered extremely sensitive to radiation-induced damage. Earlier studies have shown that exposure to radiation can drastically affect motility and morphology and cause intense vacuolization in human spermatozoa [77, 78]. Studies conducted in people exposed to radiations from the atomic bombings of Hiroshima and Nagasaki [79] and the Chernobyl incident [80] have revealed poor motility in the spermatozoa of ejaculates from these men. Even though the mechanism behind the radiation-induced defective sperm motility is not clearly elucidated yet, significant reduction in the expression of cation channel of sperm associated1 (CatSper 1) and cation channel of sperm associated2 (CatSper2) genes [81], and 
other sperm motility-associated proteins were observed in mice [82]. Kesari et al. [83] reported that as low as $850 \mathrm{MHz}$ of non-ionizing radiation impaired sperm motility in human. The decrease in motility and its recovery from radiation-induced assault is dose-dependent. Exposure to a threshold of 0.1 Gy of ionizing radiation caused significant decrease in sperm parameters, which was reversible after 918 months. However, exposure to $>3$ Gy caused permanent infertility [84]. Considering the extreme sensitivity of the testicular tissue to radiation-induced damages, it is a common practice to use lead shields to minimize the exposure to testes during radiotherapy.

\section{Heat Exposure}

Scrotal temperature is $2-5^{\circ} \mathrm{C}$ lower than the core body temperature in mammals, which is essential for normal spermatogenesis to take place. It is suggested that high heat exposure may perturb regulation of intrascrotal temperature and increase intratesticular temperature, both of which have drastic effects on semen quality [85]. A study performed on mice demonstrated that heat exposure deleteriously affected sperm motility and morphology and resulted in delayed conception [86]. Gong et al. [87] demonstrated that heat stress decreases sperm motility by downregulating mitochondrial activity and decreasing ATP levels. Transient scrotal hyperthermia was shown to cause reversible reduction in proteins required for spermatogenesis, gamete interaction, and motility [88]. Decreased antioxidant level, mitochondrial degeneration, and alteration in protein expression pattern have shown to be associated with poor motility [89]. Heat stress is also known to cause dephosphorylation of glycogen synthase kinase- $3 \alpha$ (GSK), a negative regulator of sperm motility and interference in mitochondrial remodeling. Therefore, men exposed to higher temperatures due to their occupation (bakers, foundry workers, welders) [90] and other factors which increase the intratesticular temperature such as sedentary work habits [91], wearing tight under garments [92], and frequent sauna use [93] may have an increased risk of defective sperm motility.

\section{Environmental Factors and Sperm Motility}

Due to a rapid increase in industrialization and urbanization, our environment is highly polluted by various natural and synthetic chemical agents generated by industrial or agricultural activities. Environmental contaminants, especially those with endocrine-disrupting function, are suspected to interfere with normal spermatogenesis and decrease the semen quality and human fertility. The published data available in the literature show that various environmental chemicals, such as pesticides, polychlorinated biphenyls [94], bisphenol A [95], glycol ethers [96], perfluoronated compounds [97], dioxins and dioxin-like compounds [98], phthalates [94], heavy metals
[99], dichloro-diphenyl-trichloroethane [100], and plasticizers [101] have adverse effects on sperm motility.

\section{Psychological Stress}

Psychological stress is an "emotional experience" accompanied by several biochemical, physiological, and behavioral changes or responses. During the events of stress, corticosterone elevation suppresses testosterone and inhibin levels, thereby causing alteration in testicular microenvironment [102]. Studies have shown a negative effect of psychological stress with sperm progressive motility [103]. Stress can affect male fertility through different mechanisms, mostly through altering testosterone secretion and through disruption of the blood-testis barrier [104]. Inhibition of the hypothalamicpituitary-gonadal axis via the inhibitory effect of gonadotropin-inhibitory hormone [105] and activation of the hypothalamic-pituitary-adrenal axis by producing an inhibitory effect on hypothalamic-pituitary-gonadal and Leydig cells, consequently impairs spermatogenesis [106]. The effect of psychological stress on reduced sperm motility could also be due to increased nitric oxide (NO) level. Excessive NO generated during psychological stress can produce peroxinitrite radicals $\left(\mathrm{ONOO}^{-}\right)$that causes oxidative damage and mitochondrial dysfunction, thereby causing reduced motility [107]. Nevertheless, it is encouraging to note that the impact of psychological stress on sperm motility or quality seems to be modifiable and reversible [104].

\section{Infections and Sperm Motility}

Microbial infection is also known to affect reproductive outcome. Sexually transmitted diseases caused by bacterial, fungal, and viral pathogens can significantly decrease semen quality and can be a contributing factor for male infertility [108]. Presence of small amount of these pathogens is shown to decrease sperm motility. Experimental evidence suggest that bacteriospermia decreases sperm motility significantly due to bacterial infections, leucocyte accumulation (leukocytospermia), antibody buildup, inflammation and oxidative stress [109]. Chlamydia trachomatis [110] and Ureaplasma sp. [111] infections are reported to affect sperm motility. Similarly, Burrello et al. [112] reported that infections caused by Candida albicans, a pathogenic yeast, decreased sperm motility significantly by reducing mitochondrial membrane potential and increasing apoptosis of human spermatozoa in vitro. Pathogens like hepatitis B virus [113], human papillomaviruses [114], herpes simplex viruses [115], and adeno-associated virus [116] were associated with significant reduction in sperm parameters, especially progressive motility. A recent report suggests that infection with SARS-Cov-2 coronavirus in men can lead to low sperm count and poor motility for 90 days following infection [117]. It is not explicit if sperm motility improves following any specific (antibacterial/antiviral/ 
antifungal) therapy in men with these infections. However, Garolla et al. [118] observed improvement in progressive motility in HPV-infected men after HPV adjuvant vaccination.

\section{Signaling Mechanisms Involved in Sperm Motility}

Motility is a complex physiological property of spermatozoa, which is dependent upon many extrinsic and intrinsic factors (Fig. 3). Several complex signaling pathways contribute to sperm motility such as cyclic adenosine monophosphate (cAMP)/protein kinase A and phosphoinositide 3-kinase signaling, which are mediated through calcium ion $\left(\mathrm{Ca}^{2+}\right)$, bicarbonate ion $\left(\mathrm{HCO}_{3}{ }^{-}\right)$, or both [8]. The less investigated DAGMAPK (ERK1/2) [Diacylglycerol-mitogen activated protein kinase (extracellular signal regulated kinase $1 / 2$ )] pathway is also involved in sperm motility signaling. This pathway is regulated at the membrane level by ion channels, such as CatSper and voltage-dependent calcium channel, and inhibited by $\mathrm{Ca}^{2+}$-ATPase, which promotes the $\mathrm{Ca}^{2+}$ influx process. Moreover, $\mathrm{HCO}_{3}{ }^{-}$, through the sodium $\left(\mathrm{Na}^{+}\right)$-bicarbonate $\left(\mathrm{Na}^{+}-\mathrm{HCO}_{3}{ }^{-}\right)$co-transporters, enhances the activation of downstream soluble adenylate cyclase (sAC) along with calcium, which promotes motility through elevation of
cAMP (Fig. 3). Intracellular sperm $\mathrm{pH}$ regulation is also governed by hydrogen ion $\left(\mathrm{H}^{+}\right)$efflux and other ions, thereby activating the opening of CatSper and increasing the intracellular $\mathrm{Ca}^{2+}$ reservoir [119]. Hence, sperm motility is interconnected and associated with different physiological changes that are solely dependent upon the intracellular signaling pathways and post-translational modifications.

\section{$\mathrm{Ca}^{2+}$ as a First Messenger in Achieving Sperm Motility}

$\mathrm{Ca}^{2+}$ is a fundamental messenger, which regulates capacitation, acrosome reaction, and hyperactivated motility. In human sperm, calcium influx is modulated by various mechanisms, such as increase in membrane permeability by loss of cholesterol from the sperm membrane, depolarization, inhibition of $\mathrm{Ca}^{2+}$-ATPase pump, activation of voltage-dependent calcium channels, and CatSper [8]. Compared to 100 to $200 \mathrm{nM}$ resting calcium concentration that is needed for normal motility, an increase in the intracellular calcium level is needed for the spermatozoa to attain hyperactivated motility in the female reproductive tract [120]. The primary role of calcium is to activate $\mathrm{sAC}$, which in turn further activates downstream signaling molecules. Inhibition of calcium influx by blocking $\mathrm{Ca}^{2+}$ channels has been demonstrated to cause male subfertility by preventing acrosomal exocytosis in humans [121].

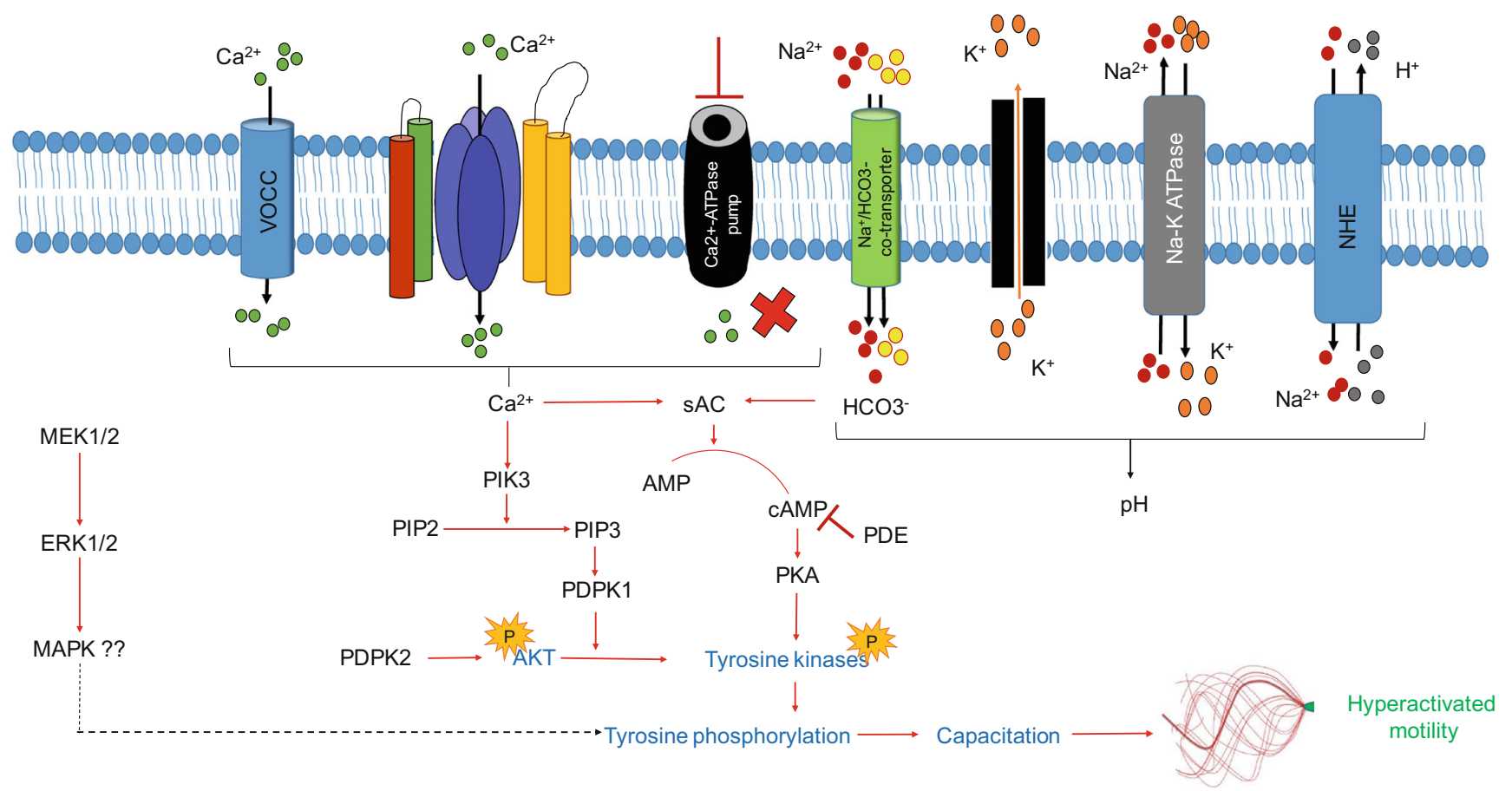

Fig. 3 Signaling mechanisms involved in regulation of motility in human spermatozoa. AKT, alpha serine/threonine-protein kinase; AMP, adenosine monophosphate; ATP, adenosine triphosphate; cAMP, cyclic adenosine monophosphate; $\mathrm{Ca}^{2+}$, calcium ion; ERK1/2, extracellular signal regulated kinase; $\mathrm{H}^{+}$, hydrogen ion; $\mathrm{HCO}_{3}{ }^{-}$, bicarbonate ion; $\mathrm{K}^{+}$, potassium ion; MAPK, mitogen activated protein kinase; MEK1/2, mitogen activated protein kinase kinase ; $\mathrm{Na}^{2+}$, sodium ion; NHE, sodium- hydrogen exchanger; P, phosphorylation; PDE, phosphodiesterase; PDPK1, 3-phosphoinositide dependent protein kinase 1; PDPK2, 3phosphoinositide dependent protein kinase 2; PIK3, phosphoinositide 3kinase; PIP2, phosphatidylinositol 4-5-bisphosphate; PIP3, phosphatidylinositol $(3,4,5)$-triphosphate; PKA, protein kinase A; sAC, soluble adenylate cyclase; VOCC, voltage-dependent calcium channel 


\section{Role of CAMP}

Cellular level of cAMP, a second messenger, is controlled by adenylate cyclases, which catalyze the conversion of ATP to cAMP with the release of inorganic phosphate [122]. Reduced level of cAMP is associated with reduced motility and infertility. G-protein-activated transmembrane adenylate cyclase and SAC are the two types of mammalian adenylate cyclases. Even though both types of adenyl cyclases are present in spermatozoa, motility appears to be solely regulated by sAC. sAC is activated by $\mathrm{Ca}^{2+}$ and bicarbonate directly and acts as a sensor for ATP, $\mathrm{Ca}^{2+}$, and $\mathrm{HCO}_{3}{ }^{-} /$carbon dioxide/pH at different intracellular sites. Importantly, sAC undertakes the task of converting ATP to cAMP, a secondary messenger that activates the protein kinase A pathway.

\section{Role of $\mathrm{HCO}_{3}{ }^{-}$in Regulation of Sperm Motility}

During the journey of sperm in the female reproductive tract, it is the bicarbonate ion that creates an alkaline environment for spermatozoa to achieve hyperactivated motility. Bicarbonate is transported into sperm through the sodium-bicarbonate cotransporters which is essential for capacitation and also a direct activator of sAC [123]. Upon its entry into the cell, it increases the intracellular $\mathrm{pH}$ and causes hyperpolarization of the membrane. Apart from the voltage-gated proton channel and $\mathrm{Na}^{+} / \mathrm{H}^{+}$exchanger, transport of bicarbonate into the sperm contributes significantly to the regulation of $\mathrm{pH}$ [119]. Hence, $\mathrm{Ca}^{2+}$ and $\mathrm{HCO}_{3}{ }^{-}$concentrations act through the sAC/cAMP/ protein kinase A pathway to achieve hyperactivated motility. Levels of bicarbonate lower than the physiologic level in the ejaculate have also shown to cause reduction in sperm motility [124]. Sperm functional changes, such as capacitation and acrosome reaction, are imperative for successful fertilization, which is also regulated by $\mathrm{HCO}_{3}{ }^{-}$. As early as $1 \mathrm{~min}$ after bicarbonate exposure to spermatozoa, a peak in cAMP level can be observed, which rapidly evokes frequent flagellar beats and decreases beat asymmetry [125].

\section{Protein Tyrosine Phosphorylation}

An increase in protein tyrosine phosphorylation is a hallmark of capacitation and hyperactivated motility in human spermatozoa. Most pathways studied in sperm motility belong to a family of protein tyrosine's that get inevitably phosphorylated during the event of hyperactivation. Phosphorylation of both serine/threonine and tyrosine proteins in human spermatozoa has been reported during capacitation [126]. Among these, the tyrosine kinases Src fibrous growth factor receptor 1 (FGFR) and Abelson murine leukemia (ABL1) are known to be well associated with tyrosine phosphorylation in mammalian sperm. A-kinase-anchoring proteins (AKAP4), calcium binding tyrosine phosphorylation regulated proteins (CABYR), heat shock protein 90 (HSP90), and $95 \mathrm{kDa}$ FS proteins that are present in the sperm flagellum have been defined as targets of tyrosine kinases [8].

\section{Sperm Motility and Infertility}

Human ejaculate is highly heterogenous with respect to the types of cells present, motility pattern, and the quality of spermatozoa. Presence of immotile sperm in the ejaculate is not unprecedented and can arise because of testicular and/or epididymal dysfunction due to various risk factors, as discussed earlier. Clinically, presence of motile and morphologically normal sperm provides evidence for fertility potential among infertile patients. Based on the results from a study conducted on 4500 normozoospermic men from 14 different countries, the baseline for normal sperm characteristics was established by World Health Organization [127]. Like oligozoospermia [128], asthenozoospermia [29, 126] is also strongly correlated with infertility which suggests that motility is an equally important semen parameter to achieve pregnancy.

\section{Importance of Motility in Planning Therapeutic Insemination Procedures}

To decide upon effective treatment for correcting infertility, infertility specialists depend upon semen parameters of male partner. Motility is one such parameter which plays an important role in deciding the appropriate therapeutic insemination option for the infertile couple. In general, to recommend intrauterine insemination (IUI), one should be able to extract at least 5 million motile sperm from the ejaculate; in vitro fertilization (IVF) is recommended when 2 to 5 million motile sperm can be extracted; and intracytoplasmic sperm injection (ICSI) is recommended when samples yield less than 2 million motile spermatozoa. Kinematic parameters, such as straight line velocity (VSL) and curvilinear velocity (VCL), have prognostic value in predicting the fertilization potential of spermatozoa $[129,130]$. If the spermatozoa have a VCL greater than $65 \mu \mathrm{m} / \mathrm{s}$ and straight line velocity (STR) greater than $40 \mu \mathrm{m} / \mathrm{s}$, IVF should be considered. If the velocities are lower than these values, to improve the fertilization rate ICSI is recommended, even if there is adequate percentage of motile spermatozoa to perform IVF [131].

\section{Motility and IUI Pregnancy}

Sperm motility as a predictor of pregnancy in patients undergoing IUI has been a topic of discussion. Several studies have confirmed that the total progressively motile sperm count in fresh ejaculate does not have any prognostic value in predicting pregnancy outcome in IUI cycles [132-134]. However, the number of inseminated progressively motile 
spermatozoa (NIPMS) was considered a better predictive marker [135]. To achieve the best pregnancy rate in IUI, at least 5 million motile spermatozoa are thought to be essential [136]. A systematic review conducted by Ombelet et al. [137] proposed that IUI can still be tried with an NIPMS of more than 1 million before directing the patient to IVF. However, the pregnancy rate in such circumstances is expected to be low. In a retrospective study comprised of 1166 couples undergoing IUI cycles, Lemmens et al. [138] found that pregnancy probability significantly decreased when the NIPMS was less than 1 million. In the case of insemination with cryopreserved semen samples, total number of motile sperm less than 20 million significantly decreases pregnancy rate [139], possibly due to the poor functional competence of frozenthawed spermatozoa.

\section{Motility and IVF Pregnancy}

It has been established that spermatozoa having at least $30 \%$ motility and $15 \%$ progressive motility are required to perform IVF [140]. Sperm motility is known to have a strong correlation with IVF success and pregnancy outcome [141]. Superior sperm kinematic parameters are also considered to improve IVF outcome. The percentage of motile spermatozoa with an average path velocity (VAP) between 10 and $20 \mathrm{~m} / \mathrm{s}$ were known to significantly increase success rates during IVF [142]. Donnelly et al. [141] reported that values for VAP, VSL, and VCL were significantly higher in samples that produced $>50 \%$ fertilization, indicating positive correlation between progressive motility and fertilization outcome. Contrary to these reports, Moghadam et al. [143] reported that motility did not enhance fertilization rate or improve pregnancy outcome through IVF. Further, with the advent of ICSI, the use of conventional IVF practice has drastically reduced [144].

\section{Motility and ICSI}

Motility is an important parameter in ICSI, as it helps the embryologist in picking a viable spermatozoon for microinjection, especially in case of absolute asthenozoospermia or if the spermatozoa are retrieved by testicular sperm aspiration. Apart from poor fertilization due to injection of non-viable spermatozoa into the oocyte, lack of motility in the sample may have an indirect negative effect on the fertilization outcome due to the delay in completion of microinjection procedure. Identifying a suitable viable spermatozoon is challenging which may potentially cause delay in completion of the ICSI procedure. Bartolacci et al. [145] in a recent retrospective study of 1266 ICSI cycles reported that low sperm motility and concentration compromise fertilization and blastocyst rates but have no impact on the implantation potential of the obtained blastocysts or rate of top quality blastocyst formation. These results are consistent with a study conducted by Mazzilli et al. [146] that included 1219 couples undergoing ICSI cycles with preimplantation aneuploidy tests. It was proposed that poor sperm motility could lower fertilization rates and impair the developmental competence of early embryos but had no effect on pregnancy rate or euploidy of the obtained blastocysts, whereas Miller and Smith [147] reported that defective motility is not linked to poor fertilizing ability in ICSI. It is instead related to developmental arrest at the cleavage stage (day 3 embryos) or decreased rate of blastocyst formation. Sperm motility was also shown to be positively associated with the quality of the sperm nucleus [148], thus showing an added benefit to selecting the most motile sperm.

\section{Improvement in Sperm Motility In Vivo}

Efforts to ameliorate testicular sperm output or semen quality have been explored in the past with various approaches, however, with minimum success. Oral supplementation of synthetic drugs, vitamins, trace elements, and other natural compounds have been used historically for enhancing sperm motility in men (Table 2). Among these, the most widely used approaches are based on mitigating the oxidative stress in the testicular microenvironment using antioxidants. Few studies have shown the beneficial effects of oral supplementation of antioxidants or trace elements in boosting sperm motility in infertile men. Antioxidants such as vitamin E [149], coenzyme $\mathrm{Q}_{10}$ [150], L-carnitine [151], vitamin C [152], and lycopene [153], alone or in combination with trace elements like selenium [154] or zinc [155], have demonstrated improvement in sperm motility after oral administration. However, there are contradictory reports as well $[156,157]$. In a recent article, Tsounapi et al. [158] reported significant improvement in sperm motility by using avanafil or combination of avanafil plus Profetil (mixture of micronutrients- L-carnitine, L-arginine, coenzyme $\mathrm{Q}_{10}$, vitamin $\mathrm{E}$, zinc, folic acid, glutathione, and selenium). Pharmacological agents such as pentoxifylline [159] and avanafil [158], which are inhibitors of phosphodiesterase (PDE), and clomiphene citrate [160], an antiestrogenic molecule that increases endogenous serum follicle-stimulating hormone (FSH), luteinizing hormone (LH), and testosterone, are proven to enhance sperm motility in vivo.

Natural compounds and crude plant extracts (individually or as multiherbal formulations) have also been tried extensively with impressive improvement in motility. In a triple blinded randomized clinical trial conducted on 100 idiopathic infertile men, Azgomi et al. [161] reported that extracts from Withania somnifera root improved sperm motility by $57 \%$, similar to that of pentoxifylline. Even though there are not many studies on motility enhancement in human with plant extracts, several animal studies suggest the potential use of extracts in 
Table 2 Drugs, bioactive compounds, and natural products used in empirical treatments to enhance human sperm motility

\begin{tabular}{|c|c|c|}
\hline \multicolumn{2}{|l|}{ Agents } & $\begin{array}{l}\text { Mode of action } \\
\text { PDE-5 inhibitor [158] }\end{array}$ \\
\hline Drugs & $\begin{array}{l}\text { Avanafil } \\
\text { Pentoxifylline } \\
\text { Clomiphene citrate }\end{array}$ & $\begin{array}{l}\text { PDE-5 inhibitor [158] } \\
\text { PDE inhibitor, increased cAMP, decreased ROS }[185,186,159] \\
\text { Binding to estrogen receptor in hypothalamus; increased } \\
\quad \text { follicle-stimulating hormone and luteinizing hormone levels }[187,188]\end{array}$ \\
\hline $\begin{array}{l}\text { Drugs along with bioactive } \\
\text { compounds }\end{array}$ & $\begin{array}{l}\text { Clomiphene citrate + vitamin E } \\
\text { Pentoxifylline + zinc }+ \text { folic acid } \\
\text { Pentoxifylline + L-carnitine }\end{array}$ & $\begin{array}{l}\text { Not known }[189,190] \\
\text { PDE inhibitor and antioxidant }[191] \\
\text { PDE inhibitor and decreased ROS }[192,187]\end{array}$ \\
\hline $\begin{array}{l}\text { Bioactive compounds alone } \\
\text { or in combination }\end{array}$ & $\begin{array}{l}\text { Vitamin C } \\
\text { Zinc } \\
\text { Selenium } \\
\text { Coenzyme } \mathrm{Q}_{10} \\
\text { L-Carnitine } \\
\text { Zinc + folate } \\
\text { Selenium + vitamin E } \\
\text { Selenium N-Acetyl-cysteine } \\
\text { Fertilovit }\end{array}$ & $\begin{array}{l}\text { Decreased ROS [193] } \\
\text { Increased metallothioneins and decreased oxidative stress [194, 155] } \\
\text { Not known [156] } \\
\text { Decreased ROS [150, 195] } \\
\text { Increased GPX4 expression [196] } \\
\text { Not known [197] } \\
\text { Increased GPX4 expression, decreased oxidative stress }[154,198] \\
\text { Not known [199] } \\
\text { Decreased ROS [200] }\end{array}$ \\
\hline Herbal extracts & $\begin{array}{l}\text { Withania somnifera } \\
\text { Tribulus terrestris } \\
\text { Mucuna pruriens } \\
\text { Lepidium meyenii (maca) } \\
\text { Speman (multiherbal formulation) }\end{array}$ & $\begin{array}{l}\text { Enhanced enzymatic activity in seminal plasma, decreased oxidative stress [161,201] } \\
\text { Not known [202] } \\
\text { Activated antioxidant defense system and physiologic stress [203] } \\
\text { Not known [204] } \\
\text { Not known [205] }\end{array}$ \\
\hline
\end{tabular}

$c A M P$, cyclic adenosine monophosphate; $P D E$, phosphodiesterase; $R O S$, reactive oxygen species

improving sperm motility. Nayak et al. [162, 163] have shown that ethanolic extract of Moringa oleifera leaves improves sperm motility in mice treated with cyclophosphamide. Similarly, other plant extracts like Ruta chalepensis, Croton zambesicus, Shengjing (a Chinese formula of plant extracts), Panax ginseng, Nigella sativa oil, Phoenix dactylifera, Punica granatum juice, Asparagus recemosus, Tribulus terrestris, Mucuna pruriens, and Lepidium meyenii are reported to increase sperm motility in animal models and humans [164]. Agrawal et al. [165] reported the use of Speman (The Himalaya Drug Company), a multiherbal formulation, which increased sperm motility in men with oiligozoospermia.

\section{Improvement in Sperm Motility In Vitro}

Unlike other semen parameters, sperm motility is accessible to modulation under in vitro conditions, which serves as an advantage, especially for ART. A wide variety of compounds have been screened for motility enhancement in vitro (Table 3), among which the most popular agents are PDE inhibitors. Compounds like 8-methoxy isobutyl methyl xanthine (8-MeOIBMX), rolipram, RS-25344, sildenafil, tadalafil, dipyridamole, isobutyl methyl xanthine (IBMX), ibudilast, tofisopam, etazolate hydrochloride, and papaverine were shown to increase sperm motility [166, 167]. Among all PDE inhibitors tested so far, caffeine and pentoxifylline are the two nonspecific PDE inhibitors that have been used most frequently as motility stimulants for human spermatozoa [166]. But, since caffeine and pentoxifylline are known to induce premature acrosome reaction, their clinical use as sperm motility enhancers has been limited [168]. Tardif et al. [167] screened 43 commercially available compounds with reported PDE inhibitor activity, among which 6 compounds (dipyridamole, ibudilast, tofisopam, etazolate hydrochloride, papaverine, and 8-MeO-IBMX) were able to significantly increase the percentage of total and progressive motility in human spermatozoa.

Apart from PDE inhibitors, treatment of human sperm with cAMP analogues, such as dibutyryl cAMP [169], adenosine, 2-deoxyadenosine [170], or activator of adenylate cyclase enzyme, such as forskolin [171], have shown a significant increase in total motility for a short duration. However, no significant difference was observed when spermatozoa were incubated over longer periods in vitro with dibutyryl cAMP or forskolin. Aitken et al. [171] reported that exposure of cryopreserved human spermatozoa to 2-deoxyadenosine resulted in significant increases in percentage of motility. However, there is limited information available in the literature on the potential application of these compounds in ART setup. Considering the role of protein kinases in the sperm motility pathway, LY294002, an inhibitor of phosphoinositide 3-kinase, was screened for its motility enhancement property. Several studies have shown potential stimulating effect of this 
Table 3 Various pharmacologic and physiologic agents used for human sperm motility enhancement in vitro

\begin{tabular}{|c|c|c|c|}
\hline \multicolumn{3}{|l|}{ Enhancers } & \multirow{2}{*}{$\begin{array}{l}\text { Examples } \\
\text { 8-MeIBMX [206] }\end{array}$} \\
\hline \multirow[t]{11}{*}{ PDE inhibitor } & Selective inhibitors & PDE 1 & \\
\hline & & PDE 3 & Trequinsin hydrochloride [207] \\
\hline & & PDE 4 & $\begin{array}{l}\text { Rolipram, RS-25344, tofisopam, etazolate } \\
\text { hydrochloride }[206,167]\end{array}$ \\
\hline & & PDE 5 & Sildenafil, tadalafil[208-210] \\
\hline & & PDE10 & Papaverine [211] \\
\hline & Nonselective inhibit & & Dipyridamole [167] \\
\hline & & & IBMX [212] \\
\hline & & & Ibudilast [167] \\
\hline & & & Caffeine [212] \\
\hline & & & Pentoxifylline [213] \\
\hline & & & Theophylline $[212,214]$ \\
\hline \multirow{2}{*}{\multicolumn{3}{|c|}{ Adenylyl cyclase enzyme stimulators }} & Adenosine, 2-deoxyadenosine $[170,215,216]$ \\
\hline & & & Forskolin, cAMP [217] \\
\hline \multicolumn{3}{|c|}{ Calcium channel modulators (calcium chelators) } & Diltiazem, flunarizine, verapamil [218] \\
\hline \multirow{4}{*}{\multicolumn{3}{|c|}{ Vitamins and antioxidants }} & Biotin $[219,220]$ \\
\hline & & & Myoinositol [221] \\
\hline & & & $\alpha$-Tocopherol [222] \\
\hline & & & Epigallocatechin gallate [223] \\
\hline \multicolumn{3}{|l|}{ Peptides } & Spermaurin $[224]$ \\
\hline \multirow{2}{*}{\multicolumn{3}{|c|}{ Herbal medicines }} & Tribulus terrestris [183] \\
\hline & & & Mondia whitei $[184]$ \\
\hline \multirow{3}{*}{\multicolumn{3}{|c|}{ Co-culturing }} & Cumulus cells [178] \\
\hline & & & Fallopian tubal cells [225] \\
\hline & & & Vero cells [226] \\
\hline \multirow{10}{*}{\multicolumn{3}{|c|}{ Hormone and growth factors }} & Insulin and leptin [177] \\
\hline & & & Platelet activating factor $[227,176]$ \\
\hline & & & Follicular fluid $[228,229]$ \\
\hline & & & Progesterone [230] \\
\hline & & & Leukemia inhibiting factor [231] \\
\hline & & & Thyroxine [173] \\
\hline & & & Relaxin [175] \\
\hline & & & Müllerian inhibiting substance [232] \\
\hline & & & Human chorionic gonadotropin [174] \\
\hline & & & Bradykinin [233] \\
\hline \multicolumn{3}{|c|}{ High-energy molecules and prostaglandins } & Creatine phosphate [234] \\
\hline
\end{tabular}

cAMP, cyclic adenosine monophosphate; 8-MeIBMX, 8-methoxymethyl-3-isobutyl-1-methylxanthine; IBMX, 3isobutyl-1-methylxanthine; $P D E$, phosphodiesterase compound on motility in humans [172]. However, a contradictory report showed notable differences in their potency [168].

Various physiologic agents, such as progesterone, thyroxin, and Müllerian inhibiting substance, were also tried and shown to improve sperm motility in vitro [173]. However, incubation of spermatozoa with Müllerian inhibiting substance led to inhibition of protein tyrosine phosphorylation, capacitation, and acrosome membrane exocytosis. Similarly, Moosavi et al. [174] reported an increase in sperm motility after incubation of rat spermatozoa with human chorionic gonadotropin, but the study lacks detailed investigation to understand the mechanism of action.

Growth factors, such as relaxin, platelet activating factor, leukemia inhibiting factor, and follicular fluid conditioned media, were also tried in vitro for sperm motility enhancement. Most of these agents improved sperm survival in vitro [175-177]. Co-culture of spermatozoa with cumulus cells under in vitro conditions increased sperm motility and longevity [178, 179]. However, the effect of these physiologic agents on sperm motility is dependent on sample type, concentration, and incubation duration [176]. At physiological concentrations, 
bradykinin, angiotensin I, II, and III, and acetylcarnitine exhibited a direct stimulating effect on sperm motility in vitro [180].

Various vitamins and antioxidants were shown to improve sperm motility and longevity by reducing in vitro oxidative stress [181]. Few herbal medicines, rich in antioxidants such as Tribulus terrestris extract $[182,183]$ and Mondia whitei [184], have been reported to enhance sperm motility in vitro. However, the major drawback is identifying the active principle from the crude extract and avoiding batch to batch variation in the plant products since the active constituents can vary with season and geographic location.

\section{Conclusion}

Last several decades have seen a steady decline in sperm output and their functional properties such as motility in human mainly due to change in environmental and lifestyle factors. Therefore, adapting to a healthy lifestyle pattern may help in minimizing the loss of fecundity in men. Motility is a major determining factor for the successful pregnancy outcome, emphasizing the importance of research in the field of motility enhancement. Efforts to improve the sperm motility in ejaculated spermatozoa by empirical treatments with hormones, antioxidant supplements, and natural products have not shown consistent results. Considering the advantage of ex vivo manipulation of motility using pharmacological agents, specifically phosphodiesterase inhibitors, further extensive research in this aspect may prove beneficial to medically assisted or artificial insemination procedures. High-throughput screening approaches can accelerate identification of novel sperm motility enhancing agents. Further, it is essential to confirm that these motility enhancers do not exert any adverse effects on the developing embryo.

Acknowledgements Open access funding provided by Manipal Academy of Higher Education, Manipal.

Authors' contributions RD, RSH, HA, and SK wrote the manuscript and drafted the studies. RD, SK, and RSH performed the database search. HA helped with the references. GK and YZ contributed significantly to the conception and design of the study. GK and YZ supervised the research and finding of the work. SKA and NK reviewed and critically evaluated the manuscript. All authors read and approved the final draft for submission.

Funding Financial support from Indian Council of Medical Research (ICMR), Government of India (Grant No. 5/10/FR/5/2015-RCH) is thankfully acknowledged. Authors acknowledge intramural postdoctoral research funding by Manipal Academy of Higher Education (MAHE), Manipal to Hanumappa Ananda.

Data Availability Not applicable

\section{Compliance with Ethical Standards}

Conflict of Interest The authors declare that they have no conflict of interest.

Ethics Approval Not applicable

Consent for Participate Not applicable

Consent for Publication Not applicable

Code Availability Not applicable

Open Access This article is licensed under a Creative Commons Attribution 4.0 International License, which permits use, sharing, adaptation, distribution and reproduction in any medium or format, as long as you give appropriate credit to the original author(s) and the source, provide a link to the Creative Commons licence, and indicate if changes were made. The images or other third party material in this article are included in the article's Creative Commons licence, unless indicated otherwise in a credit line to the material. If material is not included in the article's Creative Commons licence and your intended use is not permitted by statutory regulation or exceeds the permitted use, you will need to obtain permission directly from the copyright holder. To view a copy of this licence, visit http://creativecommons.org/licenses/by/4.0/.

\section{References}

1. Toxicology BMiR. Biologic markers of human male reproductive health and physiologic damage. 1989.

2. Brown RL. Rate of transport of spermia in human uterus and tubes. Am J Obstet Gynecol. 1944;47(3):407-11. https://doi.org/ 10.1016/S0002-9378(15)30756-0.

3. World Health Organization. WHO laboratory manual for the Examination and processing of human semen. 2010.

4. Shlomi Barak HWGB. Clinical management of male infertility. Adult and Pediatric: Endocrinology; 2016.

5. Nayak J, Jena SR, Samanta L. Chapter 4.3 - Oxidative stress and sperm dysfunction: an insight into dynamics of semen proteome. In: Henkel R, Samanta L, Agarwal A, editors. Oxidants, Antioxidants and Impact of the Oxidative Status in Male Reproduction. Academic Press; 2019. p. 261-275.

6. Gaffney EA, Gadêlha H, Smith DJ, Blake JR, Kirkman-Brown JC. Mammalian sperm motility: observation and theory. Annu Rev Fluid Mech. 2011;43(1):501-28. https://doi.org/10.1146/ annurev-fluid-121108-145442.

7. Turner RM. Moving to the beat: a review of mammalian sperm motility regulation. Reprod Fertil Dev. 2006;18(1-2):25-38. https://doi.org/10.1071/rd05120.

8. Freitas MJ, Vijayaraghavan S, Fardilha M. Signaling mechanisms in mammalian sperm motility $\dagger$. Biol Reprod. 2016;96(1):2-12. https://doi.org/10.1095/biolreprod.116.144337.

9. Agarwal A, Mulgund A, Hamada A, Chyatte MR. A unique view on male infertility around the globe. Reprod Biol Endocrinol. 2015;13(1):37. https://doi.org/10.1186/s12958-015-0032-1.

10. Agarwal A, Sharma R, Harlev A, Esteves S. Effect of varicocele on semen characteristics according to the new 2010 World Health Organization criteria: a systematic review and meta-analysis. Asian J Andrology. 2016;18(2):163-70. https://doi.org/10.4103/ 1008-682x.172638.

11. Abd-Elmoaty MA, Saleh R, Sharma R, Agarwal A. Increased levels of oxidants and reduced antioxidants in semen of infertile men with varicocele. Fertil Steril. 2010;94(4):1531-4. https://doi. org/10.1016/j.fertnstert.2009.12.039. 
12. Zargooshi J. Sperm count and sperm motility in incidental highgrade varicocele. Fertil Steril. 2007;88(5):1470-3. https://doi.org/ 10.1016/j.fertnstert.2007.01.016.

13. Blumer CG, Fariello RM, Restelli AE, Spaine DM, Bertolla RP, Cedenho AP. Sperm nuclear DNA fragmentation and mitochondrial activity in men with varicocele. Fertil Steril. 2008;90(5): 1716-22. https://doi.org/10.1016/j.fertnstert.2007.09.007.

14. Samanta L, Agarwal A, Swain N, Sharma R, Gopalan B, Esteves $\mathrm{SC}$, et al. Proteomic signatures of sperm mitochondria in varicocele: clinical use as biomarkers of varicocele associated infertility. J Urol. 2018;200(2):414-22.

15. Buffone MG, Brugo-Olmedo S, Calamera JC, Verstraeten SV, Urrutia F, Grippo L, et al. Decreased protein tyrosine phosphorylation and membrane fluidity in spermatozoa from infertile men with varicocele. Mol Reprod Dev. 2006;73(12):1591-9. https:// doi.org/10.1002/mrd.20611.

16. Ariagno J, Mendeluk G, Furlan M, Sardi M, Chenlo P, et al. Computer-aided sperm analysis: a useful tool to evaluate patient's response to varicocelectomy. Asian J Andrology. 2017;19(4): 449-52. https://doi.org/10.4103/1008-682x.173441.

17. Kantartzi PD, Goulis C, Goulis GD, Papadimas I. Male infertility and varicocele: myths and reality. Hippokratia. 2007;11(3):99104.

18. Chu DI, Zderic SA, Shukla AR, Srinivasan AK, Tasian GE, Weiss DA et al. Does varicocelectomy improve semen analysis outcomes in adolescents without testicular asymmetry? J Pediatr Urol. 2017;13(1):76.e1-.e5. doi:https://doi.org/10.1016/j.jpurol. 2016.09.010

19. Shabana W, Teleb M, Dawod T, Elsayed E, Desoky E, Shahin A, et al. Predictors of improvement in semen parameters after varicocelectomy for male subfertility: a prospective study. Can Urol Assoc J. 2015;9(9-10):E579-82. https://doi.org/10.5489/ cuaj.2808.

20. Garg H, Kumar R. An update on the role of medical treatment including antioxidant therapy in varicocele. Asian J Androl. 2016;18(2):222-8. https://doi.org/10.4103/1008-682x.171657.

21. Wang Y, Chen F, Liang M, Chen S, Zhu Y, Zou Z, et al. Grape seed proanthocyanidin extract attenuates varicocele-induced testicular oxidative injury in rats by activating the Nrf2-antioxidant system. Mol Med Rep. 2018;17(1):1799-806. https://doi.org/10. 3892/mmr.2017.8020.

22. Chemes HE, Rawe VY. The making of abnormal spermatozoa: cellular and molecular mechanisms underlying pathological spermiogenesis. Cell Tissue Res. 2010;341(3):349-57. https://doi.org/ 10.1007/s00441-010-1007-3.

23. Leigh MW, Pittman JE, Carson JL, Ferkol TW, Dell SD, Davis $\mathrm{SD}$, et al. Clinical and genetic aspects of primary ciliary dyskinesia/Kartagener syndrome. Gen Med. 2009;11(7):473-87. https://doi.org/10.1097/GIM.0b013e3181a53562.

24. Gupta S, Handa KK, Kasliwal RR, Bajpai P. A case of Kartagener's syndrome: Importance of early diagnosis and treatment. Indian J Hum Genet. 2012;18(2):263-7. https://doi.org/10. 4103/0971-6866.100787.

25. Mirra V, Werner C, Santamaria F. Primary ciliary dyskinesia: an update on clinical aspects, genetics, diagnosis, and future treatment strategies. Front Pediatr. 2017;5(135). https://doi.org/10. 3389/fped.2017.00135.

26. Chemes HE, Rawe VY. Sperm pathology: a step beyond descriptive morphology. Origin, characterization and fertility potential of abnormal sperm phenotypes in infertile men. Hum Reprod Update. 2003;9(5):405-28. https://doi.org/10.1093/humupd/ dmg034.

27. Paoli D, Gallo M, Rizzo F, Baldi E, Francavilla S, Lenzi A, et al. Mitochondrial membrane potential profile and its correlation with increasing sperm motility. Fertil Steril. 2011;95(7):2315-9. https://doi.org/10.1016/j.fertnstert.2011.03.059.
28. Baklouti-Gargouri S, Ghorbel M, Mahmoud AB, Mkaouar-Rebai $\mathrm{E}$, Cherif M, Chakroun N, et al. Identification of a novel $\mathrm{m}$. $9588 \mathrm{G}>$ a missense mutation in the mitochondrial COIII gene in asthenozoospermic Tunisian infertile men. J Assist Reprod Genet. 2014;31(5):595-600.

29. Kao S-H, Chao H-T, Liu H-W, Liao T-L, Wei Y-H. Sperm mitochondrial DNA depletion in men with asthenospermia. Fertil Steril. 2004;82(1):66-73. https://doi.org/10.1016/j.fertnstert. 2003.11.056.

30. Ruiz-Pesini E, Lapeña A-C, Díez-Sánchez C, Pérez-Martos A, Montoya J, Alvarez E, et al. Human mtDNA haplogroups associated with high or reduced spermatozoa motility. Am J Hum Genet. 2000;67(3):682-96. https://doi.org/10.1086/303040.

31. Selvi Rani D, Vanniarajan A, Gupta NJ, Chakravarty B, Singh L, Thangaraj K. A novel missense mutation C11994T in the mitochondrial ND4 gene as a cause of low sperm motility in the Indian subcontinent. Fertil Steril. 2006;86(6):1783-5. https://doi.org/10. 1016/j.fertnstert.2006.04.044.

32. Cui D, Han G, Shang Y, Liu C, Xia L, Li L, et al. Antisperm antibodies in infertile men and their effect on semen parameters: a systematic review and meta-analysis. Clin Chim Acta. 2015;444: 29-36.

33. McLachlan RI. Basis, diagnosis and treatment of immunological infertility in men. J Reprod Immunol. 2002;57(1):35-45. https:// doi.org/10.1016/S0165-0378(02)00014-1.

34. Shibahara H, Shiraishi Y, Suzuki M. Diagnosis and treatment of immunologically infertile males with antisperm antibodies. Reprod Med Biol. 2005;4(2):133-41. https://doi.org/10.1111/j. 1447-0578.2005.00102.x.

35. Hendry WF, Hughes L, Scammell G, Pryor JP, Hargreave TB. Comparison of prednisolone and placebo in subfertile men with antibodies to spermatozoa. Lancet. 1990;335(8681):85-8. https:// doi.org/10.1016/0140-6736(90)90548-J.

36. Bronson RA, Cooper GW, Rosenfeld DL, Gilbert JV, Plaut AG. The effect of an IgA1 protease on immunoglobulins bound to the sperm surface and sperm cervical mucus penetrating ability. Fertil Steril. 1987;47(6):985-91. https://doi.org/10.1016/S00150282(16)59234-6.

37. Gould JE, Brazil CK, Overstreet JW. Sperm-immunobead binding decreases with in vitro incubation. Fertil Steril. 1994;62(1):16771. https://doi.org/10.1016/S0015-0282(16)56834-4.

38. Foresta C, Varotto A, Caretto A. Immunomagnetic method to select human sperm without sperm surface-bound autoantibodies in male autoimmune infertility. Arch Androl. 1990;24(2):221-5. https://doi.org/10.3109/01485019008986883.

39. Agarwal A. Treatment of immunological infertility by sperm washing and intrauterine insemination. Arch Androl. 1992;29(3):207-13. https://doi.org/10.3109/ 01485019208987726 .

40. Shulman S. Use of washed sperm for removal of sperm antibodies. In: David G, Price WS, (eds). Human Artificial Insemination and Semen Preservation. Boston, MA: Springer; 1980. p. 589-92. https://doi.org/10.1007/978-1-4684-8824-1_751980.

41. Gervasi MG, Visconti PE. Molecular changes and signaling events occurring in spermatozoa during epididymal maturation. Andrology. 2017;5(2):204-18. https://doi.org/10.1111/andr. 12320 .

42. Comar VA, Petersen CG, Mauri AL, Mattila M, Vagnini LD, Renzi A, et al. Influence of the abstinence period on human sperm quality: analysis of 2,458 semen samples. JBRA Assisted Reprod. 2017;21(4):306-12. https://doi.org/10.5935/1518-0557. 20170052.

43. Agarwal A, Said TM. Role of sperm chromatin abnormalities and DNA damage in male infertility. Hum Reprod Update. 2003;9(4): 331-45. https://doi.org/10.1093/humupd/dmg027. 
44. Du Plessis SS, McAllister DA, Luu A, Savia J, Agarwal A, Lampiao F. Effects of $\mathrm{H} 2 \mathrm{O} 2$ exposure on human sperm motility parameters, reactive oxygen species levels and nitric oxide levels. Andrologia. 2010;42(3):206-10. https://doi.org/10.1111/j.14390272.2009.00980.x.

45. Shen Z-Q, Shi B, Wang T-R, Jiao J, Shang X, Wu Q-J et al. Characterization of the Sperm Proteome and Reproductive Outcomes with in vitro fertilization after a reduction in male ejaculatory abstinence period. Mol Cell Proteomics. 2018: mcp.RA117.000541. https://doi.org/10.1074/mcp.RA117. 000541.

46. Alipour H, Van Der Horst G, Christiansen OB, Dardmeh F, Jørgensen N, Nielsen HI, et al. Improved sperm kinematics in semen samples collected after $2 \mathrm{~h}$ versus 4-7 days of ejaculation abstinence. Hum Reprod. 2017;32(7):1364-72. https://doi.org/10. 1093/humrep/dex101.

47. Dupesh S, Pandiyan N, Pandiyan R, Kartheeswaran J, Prakash B. Ejaculatory abstinence in semen analysis: does it make any sense? Ther Adv Reprod Health. 2020;14. https://doi.org/10.1177/ 2633494120906882.

48. Elzanaty S, Malm J, Giwercman A. Duration of sexual abstinence: epididymal and accessory sex gland secretions and their relationship to sperm motility. Hum Reprod. 2005;20(1):221-5. https:// doi.org/10.1093/humrep/deh586.

49. Ricci E, Al Beitawi S, Cipriani S, Candiani M, Chiaffarino F, Viganò $\mathrm{P}$, et al. Semen quality and alcohol intake: a systematic review and meta-analysis. Reprod BioMed Online. 2017;34(1): 38-47. https://doi.org/10.1016/j.rbmo.2016.09.012.

50. Ricci E, Noli S, Ferrari S, La Vecchia I, Cipriani S, De Cosmi V, et al. Alcohol intake and semen variables: cross-sectional analysis of a prospective cohort study of men referring to an Italian Fertility Clinic. Andrology. 2018;6(5):690-6.

51. Silva JV, Cruz D, Gomes M, Correia BR, Freitas MJ, Sousa L, et al. Study on the short-term effects of increased alcohol and cigarette consumption in healthy young men's seminal quality. Sci Rep. 2017;7:45457. https://oi.org/10.1038/srep45457.

52. de Jong AME, Menkveld R, Lens JW, Nienhuis SE, Rhemrev JPT. Effect of alcohol intake and cigarette smoking on sperm parameters and pregnancy. Andrologia. 2014;46(2):112-7. https://doi.org/10.1111/and.12054.

53. Goverde HJ, Dekker HS, Janssen HJ, Bastiaans BA, Rolland R, Zielhuis GA. Semen quality and frequency of smoking and alcohol consumption: an explorative study. Int J Fertil Menopausal Stud. 1995;40(3):135-8.

54. Vicari E, Arancio A, Giuffrida V, D'Agata R, Calogero AE. A case of reversible azoospermia following withdrawal from alcohol consumption. J Endocrinol Investig. 2002;25(5):473-6. https:// doi.org/10.1007/BF03344041.

55. Sermondade N, Elloumi H, Berthaut I, Mathieu E, Delarouzière $\mathrm{V}$, Ravel C, et al. Progressive alcohol-induced sperm alterations leading to spermatogenic arrest, which was reversed after alcohol withdrawal. Reprod BioMed Online. 2010;20(3):324-7. https:// doi.org/10.1016/j.rbmo.2009.12.003.

56. Mostafa RM, Nasrallah YS, Hassan MM, Farrag AF, Majzoub A, Agarwal A. The effect of cigarette smoking on human seminal parameters, sperm chromatin structure and condensation. Andrologia. 2018;50(3):e12910. https://doi.org/10.1111/and. 12910.

57. Dai J-B, Wang Z-X, Qiao Z-D. The hazardous effects of tobacco smoking on male fertility. Asian J Andrology. 2015;17(6):95460. https://doi.org/10.4103/1008-682x.150847.

58. Gandini L, Lombardo F, Lenzi A, Culasso F, Pacifici R, Zuccaro P et al. The in-vitro effects of nicotine and cotinine on sperm motility. Human reproduction (Oxford, England). 1997;12(4):727-33.

59. Kiziler AR, Aydemir B, Onaran I, Alici B, Ozkara H, Gulyasar T, et al. High levels of cadmium and lead in seminal fluid and blood of smoking men are associated with high oxidative stress and damage in infertile subjects. Biol Trace Elem Res. 2007;120(13):82-91.

60. Belloc S, Cohen-Bacrie M, Amar E, Izard V, Benkhalifa M, Dalléac A, et al. High body mass index has a deleterious effect on semen parameters except morphology: results from a large cohort study. Fertil Steril. 2014;102(5):1268-73. https://doi.org/ 10.1016/j.fertnstert.2014.07.1212.

61. Maldonado-Cárceles AB, Mínguez-Alarcón L, Mendiola J, Vioque J, Jørgensen N, Árense-Gonzalo JJ, et al. Meat intake in relation to semen quality and reproductive hormone levels among young men in Spain. Br J Nutr. 2019;121(4):451-60. https://doi. org/10.1017/s0007114518003458.

62. Jóźków P, Rossato M. The impact of intense exercise on semen quality. Am J Mens Health. 2017;11(3):654-62. https://doi.org/ 10.1177/1557988316669045.

63. Gorpinchenko I, Nikitin O, Banyra O, Shulyak A. The influence of direct mobile phone radiation on sperm quality. Central Eur J Urol. 2014;67(1):65-71. https://doi.org/10.5173/ceju.2014.01. art14.

64. Avendano C, Mata A, Sanchez Sarmiento CA, Doncel GF. Use of laptop computers connected to internet through Wi-Fi decreases human sperm motility and increases sperm DNA fragmentation. Fertil Steril. 2012;97(1):39-45.e2. https://doi.org/10.1016/j. fertnstert.2011.10.012.

65. Liu M-M, Liu L, Chen L, Yin X-J, Liu H, Zhang Y-H, et al. Sleep deprivation and late bedtime impair sperm health through increasing antisperm antibody production: a prospective study of 981 healthy men. Med Sci Monit. 2017. https://doi.org/10.12659/ MSM.900101.

66. Anderson K, Nisenblat V, Norman R. Lifestyle factors in people seeking infertility treatment - a review. Aust N Z J Obstet Gynaecol. 2010;50(1):8-20. https://doi.org/10.1111/j.1479828X.2009.01119.x.

67. Williams DH, Karpman E, Sander JC, Spiess PE, Pisters LL, Lipshultz LI. Pretreatment semen parameters in men with cancer. J Urol. 2009;181(2):736-40. https://doi.org/10.1016/j.juro.2008. 10.023.

68. Dias TR, Agarwal A, Pushparaj PN, Ahmad G, Sharma R. Reduced semen quality in patients with testicular cancer seminoma is associated with alterations in the expression of sperm proteins. Asian J Androl. 2020;22(1):88-93. https://doi.org/10. 4103/aja.aja_17_19.

69. Hendry WF, Stedronska J, Jones CR, Blackmore CA, Barreit A, Peckham MJ. Semen analysis in testicular cancer and Hodgkin's disease: pre- and post-treatment findings and implications for cryopreservation. Br J Urol. 1983;55(6):769-73. https://doi.org/ 10.1111/j.1464-410X.1983.tb03423.x.

70. Ding J, Shang X, Zhang Z, Jing H, Shao J, Fei Q, et al. FDAapproved medications that impair human spermatogenesis. Oncotarget. 2017;8(6):10714-25. https://doi.org/10.18632/ oncotarget.12956.

71. Levin RM, Amsterdam JD, Winokur A, Wein AJ. Effects of psychotropic drugs on human sperm motility. Fertil Steril. 1981;36(4):503-6. https://doi.org/10.1016/S0015-0282(16) 45801-2.

72. Chen SS, Shen MR, Chen TJ, Lai SL. Effects of antiepileptic drugs on sperm motility of normal controls and epileptic patients with long-term therapy. Epilepsia. 1992;33(1):149-53.

73. Banihani SA. Effect of paracetamol on semen quality. Andrologia. 2018;50(1):e12874. https://doi.org/10.1111/and.12874.

74. Banihani SA, Khasawneh FH. Effect of lansoprazole on human sperm motility, sperm viability, seminal nitric oxide production, and seminal calcium chelation. Res Pharm Sci. 2018;13(5):460-8. https://doi.org/10.4103/1735-5362.236839. 
75. Stutz G, Zamudio J, Santillán ME, Vincenti L, De Cuneo MF, Ruiz RD. The effect of alcohol, tobacco, and aspirin consumption on seminal quality among healthy young men. Arch Environ Health Int J. 2004;59(11):548-52. https://doi.org/10.1080/ 00039890409603432.

76. Du Plessis SS, Agarwal A, Syriac A. Marijuana, phytocannabinoids, the endocannabinoid system, and male fertility. J Assist Reprod Genet. 2015;32(11):1575-88. https://doi.org/ 10.1007/s10815-015-0553-8.

77. Wdowiak A, Skrzypek M, Stec M, Panasiuk L. Effect of ionizing radiation on the male reproductive system. Ann Agric Environ Med. 2019;26(2):210-6. https://doi.org/10.26444/aaem/106085.

78. Zhou DD, Hao JL, Guo KM, Lu CW, Liu XD. Sperm quality and DNA damage in men from Jilin Province, China, who are occupationally exposed to ionizing radiation. Genet Mol Res. 2016. https://doi.org/10.4238/gmr.15018078.

79. Ohkita TA. Acute Effects. J Radiat Res. 1975;16(Suppl_1):49-66. https://doi.org/10.1269/jrr.16.Suppl_1.49.

80. Andreychenko SV, Klepko AV, Gorban LV, Motryna OA, Grubska LV, Trofimenko OV. Post-Chornobyl remote radiation effects on human sperm and seminal plasma characteristics. Exp Oncol. 2016;38(4):245-51.

81. Mohammadi S, Kianmehr M, Mohammadi M, Fahimian Z, Karimimanesh E, Farazifar M, et al. Correlation between expression of CatSper1,2 and sperm parameters in the gamma irradiated adult mouse testis. Int J Radiat Biol. 2019;95(6):691-6. https:// doi.org/10.1080/09553002.2019.1552372.

82. Li HY, Zhang H. Proteome analysis for profiling infertility markers in male mouse sperm after carbon ion radiation. Toxicology. 2013;306:85-92.

83. Kesari KK, Agarwal A, Henkel R. Radiations and male fertility. Reprod Biol Endocrinol. 2018;16(1):118. https://doi.org/10.1186/ s12958-018-0431-1.

84. De Felice F, Marchetti C, Marampon F, Cascialli G, Muzii L, Tombolini V. Radiation effects on male fertility. Andrology. 2019;7(1):2-7. https://doi.org/10.1111/andr.12562.

85. Thonneau P, Bujan L, Multigner L, Mieusset R. Occupational heat exposure and male fertility: a review. Hum Reprod. 1998;13(8): 2122-5. https://doi.org/10.1093/humrep/13.8.2122.

86. Wechalekar H, Setchell BP, Peirce EJ, Ricci M, Leigh C, Breed WG. Whole-body heat exposure induces membrane changes in spermatozoa from the cauda epididymidis of laboratory mice. Asian J Androl. 2010;12(4):591-8. https://doi.org/10.1038/aja. 2010.41.

87. Gong Y, Guo H, Zhang Z, Zhou H, Zhao R, He B. Heat stress reduces sperm motility via activation of glycogen synthase kinase$3 \alpha$ and inhibition of mitochondrial protein import. Front Physiol. 2017;8(718). https://doi.org/10.3389/fphys.2017.00718.

88. Rao M, Xia W, Yang J, Hu L-X, Hu S-F, Lei H, et al. Transient scrotal hyperthermia affects human sperm DNA integrity, sperm apoptosis, and sperm protein expression. Andrology. 2016;4(6): 1054-63. https://doi.org/10.1111/andr.12228.

89. Kanter M, Aktas C, Erboga M. Heat stress decreases testicular germ cell proliferation and increases apoptosis in short term: an immunohistochemical and ultrastructural study. Toxicol Ind Health. 2013;29(2):99-113. https://doi.org/10.1177/ 0748233711425082 .

90. Laven JSE, Haverkorn MJ, Bots RSGM. Influence of occupation and living habits on semen quality in men (scrotal insulation and semen quality). Eur J Obstet Gynecol Reprod Biol. 1988;29(2): 137-41. https://doi.org/10.1016/0028-2243(88)90140-2.

91. Priskorn L, Jensen TK, Bang AK, Nordkap L, Joensen UN, Lassen $\mathrm{TH}$, et al. Is sedentary lifestyle associated with testicular function? A cross-sectional study of 1,210 men. Am J Epidemiol. 2016;184(4):284-94. https://doi.org/10.1093/aje/kwv338.
92. Mínguez-Alarcón L, Gaskins AJ, Chiu Y-H, Messerlian C, Williams PL, Ford JB, et al. Type of underwear worn and markers of testicular function among men attending a fertility center. Hum Reprod. 2018;33(9):1749-56. https://doi.org/10.1093/humrep/ dey259.

93. Saikhun J, Kitiyanant Y, Vanadurongwan V, Pavasuthipaisit K. Effects of sauna on sperm movement characteristics of normal men measured by computer-assisted sperm analysis. Int $\mathrm{J}$ Androl. 1998;21(6):358-63. https://doi.org/10.1046/j.1365-2605. 1998.00138.x.

94. Hauser R, Williams P, Altshul L, Calafat AM. Evidence of interaction between polychlorinated biphenyls and phthalates in relation to human sperm motility. Environ Health Perspect. 2005;113(4):425-30.

95. Li D-K, Zhou Z, Miao M, He Y, Wang J, Ferber J, et al. Urine bisphenol-A (BPA) level in relation to semen quality. Fertil Steril. 2011;95(2):625-30.e4. https://doi.org/10.1016/j.fertnstert.2010. 09.026 .

96. Cherry N, Moore H, McNamee R, Pacey A, Burgess G, Clyma JA, et al. Occupation and male infertility: glycol ethers and other exposures. Occup Environ Med. 2008;65(10):708-14. https://doi. org/10.1136/oem.2007.035824.

97. Governini L, Guerranti C, De Leo V, Boschi L, Luddi A, Gori M, et al. Chromosomal aneuploidies and DNA fragmentation of human spermatozoa from patients exposed to perfluorinated compounds. Andrologia. 2015;47(9):1012-9.

98. Mocarelli P, Gerthoux PM, Patterson DG, Milani S, Limonta G, Bertona M, et al. Dioxin exposure, from infancy through puberty, produces endocrine disruption and affects human semen quality. Environ Health Perspect. 2008;116(1):70-7. https://doi.org/10. 1289/ehp.10399.

99. Mendiola J, Moreno JM, Roca M, Vergara-Juárez N, MartínezGarcía MJ, García-Sánchez A, et al. Relationships between heavy metal concentrations in three different body fluids and male reproductive parameters: a pilot study. Environ Health. 2011;10(1):6. https://doi.org/10.1186/1476-069X-10-6.

100. Pant N, Kumar R, Mathur N, Srivastava SP, Saxena DK, Gujrati VR. Chlorinated pesticide concentration in semen of fertile and infertile men and correlation with sperm quality. Environ Toxicol Pharmacol. 2007;23(2):135-9. https://doi.org/10.1016/j.etap. 2006.07.012.

101. Fredricsson B, Möller L, Pousette Å, Westerholm R. Human sperm motility is affected by plasticizers and diesel particle extracts. Pharmacol Toxicol. 1993;72(2):128-33. https://doi.org/10. 1111/j.1600-0773.1993.tb00303.x.

102. Durairajanayagam D. Lifestyle causes of male infertility. Arab J Urol. 2018;16(1):10-20. https://doi.org/10.1016/j.aju.2017.12. 004.

103. Clarke RN, Klock SC, Geoghegan A, Travassos DE. Relationship between psychological stress and semen quality among in-vitro fertilization patients. Hum Reprod. 1999;14(3):753-8. https:// doi.org/10.1093/humrep/14.3.753.

104. Nargund VH. Effects of psychological stress on male fertility. Nature Rev Urol. 2015;12(7):373-82. https://doi.org/10.1038/ nrurol.2015.112.

105. Ubuka T, Son YL, Tobari Y, Narihiro M, Bentley G, Kriegsfeld L, et al. Central and direct regulation of testicular activity by gonadotropin-inhibitory hormone and its receptor. Front Endocrinol. 2014;5(8). https://doi.org/10.3389/fendo.2014.00008.

106. Kirby ED, Geraghty AC, Ubuka T, Bentley GE, Kaufer D. Stress increases putative gonadotropin inhibitory hormone and decreases luteinizing hormone in male rats. Proc Natl Acad Sci. 2009. https://doi.org/10.1073/pnas.0901176106.

107. Eskiocak S, Gozen AS, Taskiran A, Kilic AS, Eskiocak M, Gulen S. Effect of psychological stress on the L-arginine-nitric oxide pathway and semen quality. Braz J Med Biol Res. 2006;39:581-8. 
108. Gimenes F, Souza RP, Bento JC, Teixeira JJV, Maria-Engler SS, Bonini MG, et al. Male infertility: a public health issue caused by sexually transmitted pathogens. Nature Rev Urol. 2014;11(12): 672-87. https://doi.org/10.1038/nrurol.2014.285.

109. Shang Y, Liu C, Cui D, Han G, Yi S. The effect of chronic bacterial prostatitis on semen quality in adult men: a meta-analysis of case-control studies. Sci Rep. 2014;4(1):7233. https://doi.org/10. 1038/srep07233.

110. Eley A, Pacey AA, Galdiero M, Galdiero M, Galdiero F. Can Chlamydia trachomatis directly damage your sperm? Lancet Infect Dis. 2005;5(1):53-7. https://doi.org/10.1016/S14733099(04)01254-X.

111. Zhou YH, Ma HX, Shi XX, Liu Y. Ureaplasma spp. in male infertility and its relationship with semen quality and seminal plasma components. J Microbiol Immunol Infect. 2018;51(6): 778-83. https://doi.org/10.1016/j.jmii.2016.09.004.

112. Burrello N, Salmeri M, Perdichizzi A, Bellanca S, Pettinato G, D'Agata R, et al. Candida albicans experimental infection: effects on human sperm motility, mitochondrial membrane potential and apoptosis. Reprod BioMed Online. 2009;18(4):496-501. https:// doi.org/10.1016/S1472-6483(10)60125-3.

113. Lorusso F, Palmisano M, Chironna M, Vacca M, Masciandaro P, Bassi E, et al. Impact of chronic viral diseases on semen parameters. Andrologia. 2010;42(2):121-6.

114. Foresta C, Garolla A, Zuccarello D, Pizzol D, Moretti A, Barzon L, et al. Human papillomavirus found in sperm head of young adult males affects the progressive motility. Fertil Steril. 2010;93(3): 802-6. https://doi.org/10.1016/j.fertnstert.2008.10.050.

115. Kapranos N, Petrakou E, Anastasiadou C, Kotronias D. Detection of herpes simplex virus, cytomegalovirus, and Epstein-Barr virus in the semen of men attending an infertility clinic. Fertil Steril. 2003;79: 1566-70. https://doi.org/10.1016/S0015-0282(03)00370-4.

116. Rohde V, Erles K, Sattler HP, Derouet H, Wullich B, Schlehofer JR. Detection of adeno-associated virus in human semen: does viral infection play a role in the pathogenesis of male infertility? Fertil Steril. 1999;72(5):814-6.

117. Segars J, Katler Q, McQueen DB, Kotlyar A, Glenn T, Knight Z, et al. Prior and novel coronaviruses, coronavirus disease 2019 (COVID$19)$, and human reproduction: what is known? Fertil Steril. 2020;113(6):1140-9. https://doi.org/10.1016/j.fertnstert.2020.04.025.

118. Garolla A, De Toni L, Bottacin A, Valente U, De Rocco PM, Di Nisio A, et al. Human papillomavirus prophylactic vaccination improves reproductive outcome in infertile patients with HPV semen infection: a retrospective study. Sci Rep. 2018;8(1):912. https://doi.org/10.1038/s41598-018-19369-z.

119. Mishra AK, Kumar A, Swain DK, Yadav S, Nigam R. Insights into $\mathrm{pH}$ regulatory mechanisms in mediating spermatozoa functions. Vet World. 2018;11(6):852-8. https://doi.org/10.14202/ vetworld.2018.852-858.

120. Kirichok Y, Lishko PV. Rediscovering sperm ion channels with the patch-clamp technique. Mol Hum Reprod. 2011;17(8):47899. https://doi.org/10.1093/molehr/gar044.

121. Benoff S, Cooper GW, Hurley I, Mandel FS, Rosenfeld DL, Scholl GM, et al. The effect of calcium ion channel blockers on sperm fertilization potential. Fertil Steril. 1994;62(3):606-17. https://doi.org/10.1016/S0015-0282(16)56953-2.

122. Steegborn C. Structure, mechanism, and regulation of soluble adenylyl cyclases - similarities and differences to transmembrane adenylyl cyclases. Biochim Biophys Acta (BBA) - Mol Basis Dis. 2014;1842(12, Part B):2535-47. https://doi.org/10. 1016/j.bbadis.2014.08.012.

123. Pereira R, Sa R, Barros A, Sousa M. Major regulatory mechanisms involved in sperm motility. Asian J Andrology. 2017;19(1):5-14. https://doi.org/10.4103/1008-682x.167716.

124. Yutaka T, Naomichi O, Yoshiki S. The activating effects of bicarbonate on sperm motility and respiration at ejaculation. Biochim
Biophys Acta Gen Subj. 1987;924(3):519-29. https://doi.org/10. 1016/0304-4165(87)90168-1.

125. Luconi M, Porazzi I, Ferruzzi P, Marchiani S, Forti G, Baldi E. Tyrosine phosphorylation of the A kinase anchoring protein 3 (AKAP3) and soluble adenylate cyclase are involved in the increase of human sperm motility by bicarbonate. Biol Reprod. 2005;72(1): 22-32. https://doi.org/10.1095/biolreprod.104.032490.

126. Amaral A, Paiva C, Attardo Parrinello C, Estanyol JM, Ballescà $\mathrm{JL}$, Ramalho-Santos J, et al. Identification of proteins involved in human sperm motility using high-throughput differential proteomics. J Proteome Res. 2014;13(12):5670-84. https://doi.org/10. 1021/pr500652y.

127. Cooper TG, Noonan E, von Eckardstein S, Auger J, Baker HWG, Behre HM, et al. World Health Organization reference values for human semen characteristics. Hum Reprod Update. 2009;16(3): 231-45. https://doi.org/10.1093/humupd/dmp048.

128. McLachlan RI. Approach to the patient with oligozoospermia. J Clin Endocrinol Metab. 2013;98(3):873-80. https://doi.org/10. 1210/jc.2012-3650.

129. Tan O, Ha T, Carr BR, Nakonezny P, Doody KM, Doody KJ. Predictive value of postwashed total progressively motile sperm count using CASA estimates in 6871 non-donor intrauterine insemination cycles. J Assist Reprod Genet. 2014;31(9):1147-53. https://doi.org/10.1007/s10815-014-0306-0.

130. Joshi N, Kodwany G, Balaiah D, Parikh M, Parikh F. The importance of computer-assisted semen analysis and sperm function testing in an IVF program. Int J Fertil Menopausal Stud. 1996;41(1):46-52.

131. Larsen L, Scheike T, Jensen TK, Bonde JP, Ernst E, Hjollund NH, et al. Computer-assisted semen analysis parameters as predictors for fertility of men from the general population. Hum Reprod. 2000;15(7):1562-7.

132. Mankus EB, Holden AE, Seeker PM, Kampschmidt JC, McLaughlin JE, Schenken RS, et al. Prewash total motile count is a poor predictor of live birth in intrauterine insemination cycles. Fertil Steril. 2019;111(4):708-13. https://doi.org/10.1016/j. fertnstert.2018.12.025.

133. Lemmens L, Kos S, Beijer C, Brinkman JW, van der Horst FA, van den Hoven L, et al. Predictive value of sperm morphology and progressively motile sperm count for pregnancy outcomes in intrauterine insemination. Fertil Steril. 2016;105(6):1462-8. https:// doi.org/10.1016/j.fertnstert.2016.02.012.

134. Akanji Tijani H, Bhattacharya S. The role of intrauterine insemination in male infertility. Hum Fertil. 2010;13(4):226-32. https:// doi.org/10.3109/14647273.2010.533811.

135. Tomlinson M, Lewis S, Morroll D. Sperm quality and its relationship to natural and assisted conception: British Fertility Society Guidelines for practice. Hum Fertil. 2013;16(3):175-93. https:// doi.org/10.3109/14647273.2013.807522.

136. Group TECW. Intrauterine insemination. Hum Reprod Update. 2009;15(3):265-77. https://doi.org/10.1093/humupd/dmp003.

137. Ombelet W, Dhont N, Thijssen A, Bosmans E, Kruger T. Semen quality and prediction of IUI success in male subfertility: a systematic review. Reprod BioMed Online. 2014;28(3):300-9. https://doi.org/10.1016/j.rbmo.2013.10.023.

138. Lemmens L, Kos S, Beijer C, Brinkman JW, van der Horst FAL, van den Hoven L, et al. Predictive value of sperm morphology and progressively motile sperm count for pregnancy outcomes in intrauterine insemination. Fertil Steril. 2016;105(6):1462-8. https:// doi.org/10.1016/j.fertnstert.2016.02.012.

139. Hajder E. Mithad Hajder1, Elmira Hajder2, Amela Husic2. medical archives. 2016:39.

140. Michelmann HW. Minimal criteria of sperm quality for insemination and IVF therapy. Int J Androl. 1995;18(Suppl 2):81-7. 
141. Donnelly ET, Lewis SE, McNally JA, Thompson W. In vitro fertilization and pregnancy rates: the influence of sperm motility and morphology on IVF outcome. Fertil Steril. 1998;70(2):305-14.

142. Liu DY, Clarke GN, Baker HWG. Relationship between sperm motility assessed with the Hamilton-Thorn motility analyzer and fertilization rates in vitro. J Androl. 1991;12(4):231-9. https://doi. org/10.1002/j.1939-4640.1991.tb00258.x.

143. Moghadam KK, Nett R, Robins JC, Thomas MA, Awadalla SG, Scheiber MD, et al. The motility of epididymal or testicular spermatozoa does not directly affect IVF/ICSI pregnancy outcomes. J Androl. 2005;26(5):619-23. https://doi.org/10.2164/jandrol.05018.

144. Dang VQ, Vuong LN, Ho TM, Ha AN, Nguyen QN, Truong BT, et al. The effectiveness of ICSI versus conventional IVF in couples with non-male factor infertility: study protocol for a randomised controlled trial. Human Reprod Open. 2019;2019(2):hoz006. https://doi.org/10.1093/hropen/hoz006.

145. Bartolacci A, Pagliardini L, Makieva S, Salonia A, Papaleo E, Viganò P. Abnormal sperm concentration and motility as well as advanced paternal age compromise early embryonic development but not pregnancy outcomes: a retrospective study of 1266 ICSI cycles. J Assist Reprod Genet. 2018;35(10):1897-903.

146. Mazzilli R, Cimadomo D, Vaiarelli A, Capalbo A, Dovere L, Alviggi E, et al. Effect of the male factor on the clinical outcome of intracytoplasmic sperm injection combined with preimplantation aneuploidy testing: observational longitudinal cohort study of 1,219 consecutive cycles. Fertil Steril. 2017;108(6):961-72. e3.

147. Miller JE, Smith TT. The effect of intracytoplasmic sperm injection and semen parameters on blastocyst development in vitro. Hum Reprod. 2001;16(5):918-24.

148. Nosrati R, Vollmer M, Eamer L, San Gabriel MC, Zeidan K, Zini A, et al. Rapid selection of sperm with high DNA integrity. Lab Chip. 2014;14(6):1142-50. https://doi.org/10.1039/ C3LC51254A

149. Eskenazi B, Kidd SA, Marks AR, Sloter E, Block G, Wyrobek AJ. Antioxidant intake is associated with semen quality in healthy men. Hum Reprod. 2005;20(4):1006-12. https://doi.org/10.1093/ humrep/deh725.

150. Balercia G, Buldreghini E, Vignini A, Tiano L, Paggi F, Amoroso $\mathrm{S}$, et al. Coenzyme Q10 treatment in infertile men with idiopathic asthenozoospermia: a placebo-controlled, double-blind randomized trial. Fertil Steril. 2009;91(5):1785-92.

151. Costa M, Canale D, Filicori M, D'Lddio S, Lenzi A. L-carnitine in idiopathic asthenozoospermia: a multicenter study. Italian Study Group on Carnitine and Male Infertility. Andrologia. 1994;26(3):155-9.

152. Akmal M, Qadri JQ, Al-Waili NS, Thangal S, Haq A, Saloom $\mathrm{KY}$. Improvement in human semen quality after oral supplementation of vitamin C. J Med Food. 2006;9(3):440-2. https://doi.org/ 10.1089/jmf.2006.9.440.

153. Gupta NP, Kumar R. Lycopene therapy in idiopathic male infertility - a preliminary report. Int Urol Nephrol. 2002;34(3):369-72. https://doi.org/10.1023/A:1024483520560.

154. Moslemi M, Tavanbakhsh S. Selenium-vitamin E supplementation in infertile men: effects on semen parameters and pregnancy rate. Int J Gen Med. 2011;4:99-104. https://doi.org/10.2147/ IJGM.S16275

155. Omu AE, Al-Azemi MK, Kehinde EO, Anim JT, Oriowo MA, Mathew TC. Indications of the mechanisms Involved in improved sperm parameters by zinc therapy. Med Princ Pract. 2008;17(2): 108-16. https://doi.org/10.1159/000112963.

156. Scott M. Yates, Hussain, Dixon. The effect of oral selenium supplementation on human sperm motility. Br J Urol. 1998;82(1):7680. https://doi.org/10.1046/j.1464-410x.1998.00683.x.

157. Sigman M, Glass S, Campagnone J, Pryor JL. Carnitine for the treatment of idiopathic asthenospermia: a randomized, doubleblind, placebo-controlled trial. Fertil Steril. 2006;85(5):1409-14. https://doi.org/10.1016/j.fertnstert.2005.10.055.
158. Tsounapi P, Honda M, Dimitriadis F, Koukos S, Hikita K, Zachariou A, et al. Effects of a micronutrient supplementation combined with a phosphodiesterase type 5 inhibitor on sperm quantitative and qualitative parameters, percentage of mature spermatozoa and sperm capacity to undergo hyperactivation: a randomised controlled trial. Andrologia. 2018;50(8):e13071. https://doi.org/10.1111/and.13071.

159. Safarinejad MR. Effect of pentoxifylline on semen parameters, reproductive hormones, and seminal plasma antioxidant capacity in men with idiopathic infertility: a randomized double-blind placebo-controlled study. Int Urol Nephrol. 2011;43(2):315-28.

160. Rŏnnberg L. The effect of clomiphene treatment on different sperm parameters in men with idiopathic oligozoospermia. Andrologia. 1980;12(3):261-5.

161. Nasimi Doost Azgomi R, Nazemiyeh H, Sadeghi Bazargani H, Fazljou SMB, Nejatbakhsh F, Moini Jazani A, et al. Comparative evaluation of the effects of Withania somnifera with pentoxifylline on the sperm parameters in idiopathic male infertility: a tripleblind randomised clinical trial. Andrologia. 2018;50(7):e13041. https://doi.org/10.1111/and.13041.

162. Nayak G, Honguntikar SD, Kalthur SG, D'Souza AS, Mutalik S, Setty MM, et al. Ethanolic extract of Moringa oleifera Lam. leaves protect the pre-pubertal spermatogonial cells from cyclophosphamide-induced damage. J Ethnopharmacol. 2016;182:101-9. https://doi.org/10.1016/j.jep.2016.02.003.

163. Nayak G, Vadinkar A, Nair S, Kalthur SG, D'Souza AS, Shetty P, et al. Sperm abnormalities induced by pre-pubertal exposure to cyclophosphamide are effectively mitigated by Moringa oleifera leaf extract. Andrologia. 2016;48(2):125-36.

164. Nantia EA, Moundipa PF, Monsees TK, Carreau S. Medicinal plants as potential male anti-infertility agents: a review. Basic Clin Andrology. 2009;19(3):148-58. https://doi.org/10.1007/ s12610-009-0030-2.

165. Agrawal H, Kulkarni K. Efficacy and safety of speman in patients with oligospermia: an open clinical study. Indian J Clin Pract. 2003;14.

166. Leclerc P, de Lamirande E, Gagnon C. Cyclic adenosine 3',5' monophosphate-dependent regulation of protein tyrosine phosphorylation in relation to human sperm capacitation and motility. Biol Reprod. 1996;55(3):684-92. https://doi.org/10.1095/ biolreprod55.3.684.

167. Tardif S, Madamidola OA, Brown SG, Frame L, Lefièvre L, Wyatt PG, et al. Clinically relevant enhancement of human sperm motility using compounds with reported phosphodiesterase inhibitor activity. Hum Reprod. 2014;29(10):2123-35. https://doi.org/ 10.1093/humrep/deu196.

168. Lanzafame F, Chapman MG, Guglielmino A, Gearon CM, Forman RG. Pharmacological stimulation of sperm motility. Hum Reprod. 1994;9(2):192-9. https://doi.org/10.1093/ oxfordjournals.humrep.a138481.

169. Liu J-H, Li Y, Cao Z-G, Ye Z-Q. Influences of dibutyryl cyclic adenosine monophosphate and forskolin on human sperm motility in vitro. Asian J Andrology. 2003;5(2):113-5.

170. Hammitt DG, Bedia E, Rogers PR, Syrop CH, Donovan JF, Williamson RA. Comparison of motility stimulants for cryopreserved human semen. Fertil Steril. 1989;52(3):495-502. https:// doi.org/10.1016/S0015-0282(16)60925-1.

171. Aitken RJ, Mattei A, Irvine S. Paradoxical stimulation of human sperm motility by 2-deoxyadenosine. J Reprod Fertil. 1986;78(2): 515-27. https://doi.org/10.1530/jrf.0.0780515.

172. Luconi M, Marra F, Gandini L, Filimberti E, Lenzi A, Forti G, et al. Phosphatidylinositol 3-kinase inhibition enhances human sperm motility. Hum Reprod. 2001;16(9):1931-7. https://doi. org/10.1093/humrep/16.9.1931. 
173. Mendeluk GR, Rosales M. Thyroxin is useful to improve sperm motility. Int J Fertil Steril. 2016;10(2):208-14. https://doi.org/10. 22074/ijfs.2016.4911.

174. Moosavi S, Ganji H, Ramezanikhah H, Arianmanesh M. Human chorionic gonadotropin in vitro: effects on rat sperm motility and fertilization outcome. Asian Pac J Reprod. 2018;7(5):225-8. https://doi.org/10.4103/2305-0500.241206.

175. Essig M, Schoenfeld C, Amelar RD, Dubin L, Weiss G. Stimulation of human sperm motility by relaxin. Fertil Steril. 1982;38(3):339-43. https://doi.org/10.1016/s0015-0282(16)46516-7.

176. Grassi G, Cappello N, Gheorghe MF, Salton L, Di Bisceglie C, Manieri $\mathrm{C}$, et al. Exogenous platelet-activating factor improves the motility of human spermatozoa evaluated with C.A.S.A.: Optimal concentration and incubation time. J Endocrinol Investig. 2010;33(10):684-90. https://doi.org/10.1007/BF03346670.

177. Lampiao F, Du Plessis SS. Insulin and leptin enhance human sperm motility, acrosome reaction and nitric oxide production. Asian J Andrology. 2008;10(5):799-807. https://doi.org/10. 1111/j.1745-7262.2008.00421.x.

178. Kalthur G, Kumar P, Adiga SK. Enhancement in motility of sperm co-incubated with cumulus oocyte complex (COC) in vitro. Eur J Obstet Gynecol Reprod Biol. 2009;145(2):167-71. https://doi. org/10.1016/j.ejogrb.2009.05.011.

179. Mansour RT, Aboulghar MA, Serour GI, Abbas AM, Elattar I. The life span of sperm motility and pattern in cumulus coculture. Fertil Steril. 1995;63(3):660-2. https://doi.org/10.1016/S00150282(16)57442-1.

180. Mizutani T, Schill WB. Motility of seminal plasma-free spermatozoa in the presence of several physiological compounds. Andrologia. 1985;17(2):150-6. https://doi.org/10.1111/j.14390272.1985.tb00975.x.

181. Salian SR, Nayak G, Kumari S, Patel S, Gowda S, Shenoy Y, et al. Supplementation of biotin to sperm preparation medium enhances fertilizing ability of spermatozoa and improves preimplantation embryo development. J Assist Reprod Genet. 2019;36(2):25566. https://doi.org/10.1007/s10815-018-1323-1.

182. Asadmobini A, Bakhtiari M, Khaleghi S, Esmaeili F, Mostafaei A. The effect of Tribulus terrestris extract on motility and viability of human sperms after cryopreservation. Cryobiology. 2017;75:154 9. https://doi.org/10.1016/j.cryobiol.2017.02.005.

183. Khaleghi S, Bakhtiari M, Asadmobini A, Esmaeili F. Tribulus terrestris extract improves human sperm parameters in vitro. $\mathrm{J}$ Evid Based Complement Alternative Med. 2017;22(3):407-12. https://doi.org/10.1177/2156587216668110.

184. Lampiao F, Krom D. Plessis SSd. The in vitro effects of Mondia whitei on human sperm motility parameters. Phytother Res. 2008;22(9):1272-3. https://doi.org/10.1002/ptr.2469.

185. Aparicio NJ, Schwarzstein L, De Turner EA. Pentoxifylline (BL 191) by oral administration in the treatment of asthenozoospermia. Andrologia. 1980;12(3):228-31. https://doi.org/10.1111/j.14390272.1980.tb00617.x.

186. Shen M, Chiang P, Yang R, Hong C, Chen S. Pentoxifylline stimulates human sperm motility both in vitro and after oral therapy. Br J Clin Pharmacol. 1991;31(6):711-4. https://doi.org/10. 1111/j.1365-2125.1991.tb05600.x.

187. Moradi M, Moradi A, Alemi M, Ahmadnia H, Abdi H, Ahmadi A, et al. Safety and efficacy of clomiphene citrate and L-carnitine in idiopathic male infertility: a comparative study. Urol J. 2010;7(3):188-93.

188. Check JH. Improved semen quality in subfertile males with varicocele-associated oligospermia following treatment with clomiphene citrate. Fertil Steril. 1980;33(4):423-6. https://doi.org/ 10.1016/S0015-0282(16)44661-3.

189. Ghanem H, Shaeer O, El-Segini A. Combination clomiphene citrate and antioxidant therapy for idiopathic male infertility: a randomized controlled trial. Fertil Steril. 2010;93(7):2232-5.
190. ElSheikh MG, Hosny MB, Elshenoufy A, Elghamrawi H, Fayad A, Abdelrahman S. Combination of vitamin E and clomiphene citrate in treating patients with idiopathic oligoasthenozoospermia: a prospective, randomized trial. Andrology. 2015;3(5):864-7. https://doi.org/10.1111/andr.12086.

191. Oliva A, Dotta A, Multigner L. Pentoxifylline and antioxidants improve sperm quality in male patients with varicocele. Fertil Steril. 2009;91(4 Suppl):1536-9. https://doi.org/10.1016/j. fertnstert.2008.09.024.

192. Moslemi Mehni N, Ketabchi AA, Hosseini E. Combination effect of Pentoxifylline and L-carnitine on idiopathic oligoasthenoteratozoospermia. Iran J Reprod Med. 2014;12(12): 817-24.

193. Akmal M, Qadri JQ, Al-Waili NS, Thangal S, Haq A, Saloom KY. Improvement in human semen quality after oral supplementation of vitamin C. J Med Food. 2006;9(3):440-2. https://doi.org/ 10.1089/jmf.2006.9.440.

194. Hadwan MH, Almashhedy LA, Alsalman ARS. Study of the effects of oral zinc supplementation on peroxynitrite levels, arginase activity and NO synthase activity in seminal plasma of Iraqi asthenospermic patients. Reprod Biol Endocrinol. 2014;12(1):1. https://doi.org/10.1186/1477-7827-12-1.

195. Safarinejad MR. Efficacy of coenzyme Q10 on semen parameters, sperm function and reproductive hormones in infertile men. J Urol. 2009;182(1):237-48. https://doi.org/10.1016/j.juro.2009.02.121.

196. Garolla A, Maiorino M, Roverato A, Roveri A, Ursini F, Foresta C. Oral carnitine supplementation increases sperm motility in asthenozoospermic men with normal sperm phospholipid hydroperoxide glutathione peroxidase levels. Fertil Steril. 2005;83(2): 355-61. https://doi.org/10.1016/j.fertnstert.2004.10.010.

197. Ebisch IMW, Pierik FH, De Jong FH, Thomas CMG, SteegersTheunissen RPM. Does folic acid and zinc sulphate intervention affect endocrine parameters and sperm characteristics in men? Int J Androl. 2006;29(2):339-45. https://doi.org/10.1111/j.1365-2605. 2005.00598.x.

198. Keskes-Ammar L, Feki-Chakroun N, Rebai T, Sahnoun Z, Ghozzi $\mathrm{H}$, Hammami S, et al. Sperm oxidative stress and the effect of an oral vitamin $\mathrm{E}$ and selenium supplement on semen quality in infertile men. Arch Androl. 2003;49(2):83-94. https://doi.org/10. 1080/01485010390129269.

199. Safarinejad MR, Safarinejad S. Efficacy of selenium and/or Nacetyl-cysteine for improving semen parameters in infertile men: a double-blind, placebo controlled randomized study. J Urol. 2009;181(2):741-51. https://doi.org/10.1016/j.juro.2008.10.015.

200. Wirleitner B, Vanderzwalmen P, Stecher A, Spitzer D, Schuff M, Schwerda D, et al. Dietary supplementation of antioxidants improves semen quality of IVF patients in terms of motility, sperm count, and nuclear vacuolization. Int J Vitam Nutr Res. 2012;82(6):391-8. https://doi.org/10.1024/0300-9831/a000136.

201. Ahmad MK, Mahdi AA, Shukla KK, Islam N, Rajender S, Madhukar D, et al. Withania somnifera improves semen quality by regulating reproductive hormone levels and oxidative stress in seminal plasma of infertile males. Fertil Steril. 2010;94(3):989 96. https://doi.org/10.1016/j.fertnstert.2009.04.046.

202. Salgado R, Marques-Silva M, Gonçalves E, Mathias A, Aguiar J, Wolff P. Effect of oral administration of Tribulus terrestris extract on semen quality and body fat index of infertile men. Andrologia. 2017;49(5):e12655.

203. Ahmad MK, Mahdi AA, Shukla KK, Islam N, Jaiswar SP, Ahmad S. Effect of Mucuna pruriens on semen profile and biochemical parameters in seminal plasma of infertile men. Fertil Steril. 2008;90(3):62735. https://doi.org/10.1016/j.fertnstert.2007.07.1314.

204. Gonzales GF, Cordova A, Gonzales C, Chung A, Vega K, Villena A. Lepidium meyenii (Maca) improved semen parameters in adult men. Asian J Androl. 2001;3(4):301-3. 
205. Al-Ani HKKNK. Treatment of oligozoospermic patients with a formulation of plant origin. 2013.

206. Fisch J, Behr B, Conti M. Enhancement of motility and acrosome reaction in human spermatozoa: differential activation by typespecific phosphodiesterase inhibitors. Human Reprod (Oxford, England). 1998;13(5):1248-54.

207. McBrinn RC, Fraser J, Hope AG, Gray DW, Barratt CLR. Martins da Silva SJ et al. Novel pharmacological actions of trequinsin hydrochloride improve human sperm cell motility and function. Br J Pharmacol. 2019;176(23):4521-36. https://doi.org/10.1111/bph.14814.

208. Yang Y, Ma Y, Yang H, Jin Y, Hu K, Wang HX, et al. Effect of acute tadalafil on sperm motility and acrosome reaction: in vitro and in vivo studies. Andrologia. 2014;46(4):417-22. https://doi. org/10.1111/and.12097.

209. Lefievre L, De Lamirande E, Gagnon C. The cyclic GMP-specific phosphodiesterase inhibitor, sildenafil, stimulates human sperm motility and capacitation but not acrosome reaction. J Androl. 2000;21(6):929-37.

210. Glenn DRJ, McVicar CM, McClure N, Lewis SEM. Sildenafil citrate improves sperm motility but causes a premature acrosome reaction in vitro. Fertil Steril. 2007;87(5):1064-70. https://doi.org/ 10.1016/j.fertnstert.2006.11.017.

211. Terriou P, Hans E, Cortvrindt R, Avon C, Charles O, Salzmann J, et al. Papaverine as a replacement for pentoxifylline to select thawed testicular or epididymal spermatozoa before ICSI. Gynecol Obstet Fertil. 2015;43(12):786-90. https://doi.org/10. 1016/j.gyobfe.2015.10.007.

212. Jiang CS, Kilfeather SA, Pearson RM, Turner P. The stimulatory effects of caffeine, theophylline, lysine-theophylline and 3isobutyl-1-methylxanthine on human sperm motility. Br J Clin Pharmacol. 1984;18(2):258-62. https://doi.org/10.1111/j.13652125.1984.tb02466.x.

213. Calogero AE, Fishel S, Hall J, Ferrara E, Vicari E, Green S, et al. Correlation between intracellular cAMP content, kinematic parameters and hyperactivation of human spermatozoa after incubation with pentoxifylline. Hum Reprod. 1998;13(4):911-5. https:// doi.org/10.1093/humrep/13.4.911.

214. Loughlin KR, Agarwal A. Use of theophylline to enhance sperm function. Arch Androl. 1992;28(2):99-103. https://doi.org/10. 3109/01485019208987686.

215. Shen M-R, Linden J, Chiang P-H, Chen S-S, Wu S-N. Adenosine stimulates human sperm motility via A2 receptors. J Pharm Pharmacol. 1993;45(7):650-3. https://doi.org/10.1111/j.20427158.1993.tb05671.x.

216. Mbizvo MT, Johnston RC, Baker GH. The effect of the motility stimulants, caffeine, pentoxifylline, and 2-deoxyadenosine on hyperactivation of cryopreserved human sperm. Fertil Steril. 1993;59(5):1112-7.

217. Cowart CL, London SN, Vernon MW, Pedigo NG. The effects of cyclic adenosine monophosphate, forskolin, and theophylline on motility parameters in gossypol-treated human sperm. Fertil Steril. 1994;61(5):929-34. https://doi.org/10.1016/S0015-0282(16)56708-9.

218. Hong CY, Chiang BN, Ku J, Wei YH, Fong JC. Calcium antagonists stimulate sperm motility in ejaculated human semen. Br J Clin Pharmacol. 1985;19(1):45-9. https://doi.org/10.1111/j.13652125.1985.tb02611.x.

219. Kalthur G, Salian SR, Keyvanifard F, Sreedharan S, Thomas JS, Kumar P, et al. Supplementation of biotin to sperm preparation medium increases the motility and longevity in cryopreserved human spermatozoa. J Assist Reprod Genet. 2012;29(7):631-5. https://doi.org/10.1007/s10815-012-9760-8.

220. Salian SR, Nayak G, Kumari S, Patel S, Gowda S, Shenoy Y, et al. Supplementation of biotin to sperm preparation medium enhances fertilizing ability of spermatozoa and improves preimplantation embryo development. J Assist Reprod Genet. 2019;36(2):25566. https://doi.org/10.1007/s10815-018-1323-1.
221. Palmieri M, Papale P, Della Ragione A, Quaranta G, Russo G, Russo S. In vitro antioxidant treatment of semen samples in assisted reproductive technology: effects of myo-inositol on nemaspermic parameters. Int J Endocrinol. 2016;2016:2839041. https://doi.org/10.1155/2016/2839041.

222. Donnelly ET, McClure N, Lewis SEM. The effect of ascorbate and $\alpha$ tocopherol supplementation in vitro on DNA integrity and hydrogen peroxide-induced DNA damage in human spermatozoa. Mutagenesis. 1999;14(5):505-12. https://doi.org/10.1093/mutage/14.5.505.

223. De Amicis F, Santoro M, Guido C, Russo A, Aquila S. Epigallocatechin gallate affects survival and metabolism of human sperm. Mol Nutr Food Res. 2012;56(11):1655-64. https:// doi.org/10.1002/mnfr.201200190.

224. Martinez G, Hograindleur J-P, Voisin S, Abi Nahed R. Abd El Aziz TM, Escoffier J et al. Spermaurin, an La1-like peptide from the venom of the scorpion Scorpio maurus palmatus, improves sperm motility and fertilization in different mammalian species. Mol Hum Reprod. 2016;23(2):116-31. https://doi.org/10.1093/ molehr/gaw075.

225. Kervancioglu ME, Saridogan E, Aitken RJ, Djahanbakhch O. Importance of sperm-to-epithelial cell contact for the capacitation of human spermatozoa in fallopian tube epithelial cell cocultures. Fertil Steril. 2000;74(4):780-4. https://doi.org/10.1016/S00150282(00)01514-4.

226. Wetzels AMM, Bastiaans BA, Goverde HJM, J.G. Janssen H, Rolland R. Vero cells stimulate human sperm motility in vitro. Fertil Steril. 1991;56(3):535-9. https://doi.org/10.1016/S00150282(16)54554-3.

227. Sengoku K, Tamate K, Takaoka Y, Ishikawa M. Andrology: effects of platelet activating factor on human sperm function in vitro. Hum Reprod. 1993;8(9):1443-7. https://doi.org/10.1093/ oxfordjournals.humrep.a138276.

228. Jeon B-G, Moon J-S, Kim K-C, Lee H-J, Choe S-Y, Rho G-J. Andrology: follicular fluid enhances sperm attraction and its motility in human. J Assist Reprod Genet. 2001;18(8):407-12. https://doi.org/10.1023/A:1016674302652.

229. Caille AM, Berta CL, Cuasnicú PS, Munuce MJ. Peritoneal fluid modifies the response of human spermatozoa to follicular fluid. Reprod BioMed Online. 2012;24(4):466-73.

230. Oehninger S, Sueldo C, Lanzendorf S, Mahony M, Burkman LJ, Alexander NJ, et al. Fertilization and early embrology: a sequential analysis of the effect of progesterone on specific sperm functions crucial to fertilization in vitro in infertile patients. Hum Reprod. 1994;9(7):1322-7. https://doi.org/10.1093/ oxfordjournals.humrep.a138702.

231. Attar E, Ozsait B, Bulgurcuoglu S, Serdaroglu H, Arici A. Effect of leukaemia inhibitory factor on long-term sperm motility and survival. Reprod BioMed Online. 2003;7(1):71-4. https://doi. org/10.1016/S1472-6483(10)61731-2.

232. Siow Y, Fallat ME, Amin FA, Belker AM. Müllerian inhibiting substance improves longevity of motility and viability of fresh and cryopreserved sperm. J Androl. 1998;19(5):568-72.

233. Miska W, Schill WB. Enhancement of sperm motility by bradykinin and kinin analogs. Arch Androl. 1990;25(1):63-7. https:// doi.org/10.3109/01485019008987595.

234. Fakih H, MacLusky N, DeCherney A, Wallimann T, Huszar G. Enhancement of human sperm motility and velocity in vitro: effects of calcium and creatine phosphate**Presented in part at the FortyFirst Annual Meeting of The American Fertility Society, Chicago, Illinois, September 27 to October 2, 1985. Fertil Steril. 1986;46(5): 938-44. https://doi.org/10.1016/S0015-0282(16)49839-0.

Publisher's Note Springer Nature remains neutral with regard to jurisdictional claims in published maps and institutional affiliations. 